\title{
Revising the Conceptual Framework of the International Standards: IASB Proposals Met with Support and Skepticism
}

\author{
Christopher W. Hoffman \\ Hoffman Consulting \\ 1700 La Maderia Drive SW, Palm Bay, Florida 32908, United States \\ E-mail: christopher.hoffman72@gmail.com
}

Received: January 14, 2016

doi:10.5296/wjbm.v2i1.8868
Accepted: January 27, 2016 Published: March 27, 2016

URL: http://dx.doi.org/10.5296/wjbm.v2i1.8868

\begin{abstract}
This article analyzes the current financial reporting issue regarding the updates proposed by the International Accounting Standards Board (IASB) to the Conceptual Framework for Financial Reporting. Since accounting standard-setters have embraced the notion of concepts as a guide and foundation to developing accounting standards, the IASB has concluded that there should be more importance place on developing a solid framework. Based on current literature and the fact that the Financial Accounting Standards Board (FASB) in the U.S. has a solid framework in place, the IASB has designed proposed updates to their framework and requested comments from the general public regarding those updates. This article evaluates the comments made by 72 respondents and tabulates the responses based on agree, disagree, or no comment. These results concluded that $66 \%$ of the responses were positive toward the updates, but $29 \%$ were negative. The disagreement was focused around four main topics: (1) prudence; (2) statement of profit or loss; (3) statement of other comprehensive income; and (4) rebuttable presumption for recycling. The IASB hopes to assimilate, deliberate, and disseminate the suggestions, comments, and the updates in 2016.
\end{abstract}

Keywords: Accounting standard-setter, Conceptual Framework, Financial Reporting, International Accounting, IASB 


\section{Introduction}

From early governmental laws to industry organizations providing guidance, the accounting industry has transformed from merely numbers to conceptual ideologies. The notion of the conceptual framework has provided accounting standard-setters with a solid foundation from which the accounting standards are derived. While the Financial Accounting Standards Board (FASB) in the U.S. has had a conceptual framework for some time and assisted the International Accounting Standards Board (IASB) with developing some of their own, the IASB has devised their own Conceptual Framework proposal and has requested comments from the general public regarding those proposals.

This article begins by providing some background of how the industry came to the notion of concepts and conceptual frameworks. The article then examines the literature regarding the conceptual framework model and the IASB's exposure draft. In addition, this article analyses and tabulates the responses from 72 respondents in relation to whether the comments agree or disagree with the proposed updates to the Conceptual Framework and also whether the respondents agree with the alternative views provided by a few IASB board members. Finally, the discussion and analysis of responses to each exposure draft question and research hypotheses will help to provide an understanding of how the IASB's constituents perceive the updates to the Conceptual Framework for Financial Reporting.

\section{Background/History of Topic}

\subsection{Early Approach to Standards}

Although accounting has been around for many centuries, the idea of standardized accounting rules was not realized until the early 1860s, in Germany (Uwe Fulbier \& Klein, 2014). Those first laws, the German Code of Commerce (ADHGB), were enacted to require companies to keep accounts for assets and liabilities and also to prepare an annual balance sheet (Baker \& Burlaud, 2015). This method is based on the static accounting theory which determines the company's profit through the market increases and decreases in assets and liabilities alone (Baker \& Burlaud, 2015). The shareholders of these companies were not satisfied with their dividend payments and pressured the government to adopt the dynamic accounting theory approach which determines the company's profits by matching expenses against revenues (Baker \& Burlaud, 2015). Of course, the dynamic approach became the most prominent accounting theory around the world for both practice and teaching, but standardization was still not attained (Baker \& Burlaud, 2015).

While the dynamic theory approach helped to influence the development of accounting practices and teachings, many governments, such as the German National Assembly (Uwe Fulbier \& Klein, 2014) and the United States (U.S.), and professional organizations, such as the American Association of Public Accountants (AAPA) (Zeff, 2003) and the Institute of Chartered Accountants in Scotland (ICAS) (ICAS, 2015), were beginning to understand that they required an accounting standard-setting body to develop the standards and enforce those standards upon the industry and capital markets (Zeff, 2003). Throughout the world, there were many countries that set up these standard-setting bodies and began to develop 
accounting standards or simply create more laws, but those standards and laws would be national or regional and most would not mirror those of other nations or regions (Baker \& Burlaud, 2015). In the early 1970s, it was determined that a coalition of sorts would be needed in the international market to help define a more consistent accounting standard approach and the International Accounting Standards Committee (IASC) was established by numerous countries, including Australia, Canada, Germany, and the U.S. to name a few (Deloitte, 2015).

\subsection{Fundamental Change in Approach}

With the introduction of national standard-setting bodies and the establishment of a single international body, the academic theorists behind much of the accounting laws and regulations of the past were cast aside and the professionals that were entrusted as board members of these standard-setters became the standard developers (Baker \& Burlaud, 2015). This transition also brought about the question of what the primary objective of financial reporting is or should be and prompted the U.S. Financial Accounting Standards Board (FASB) to develop the first Statement of Financial Accounting Concept (SFAC 1), Objectives of Financial Reporting by Business Enterprises, in 1978 (Baker \& Burlaud, 2015). Both FASB and IASC utilized the SFAC to develop accounting standards and further develop other elements with their respective Conceptual Frameworks (Baker \& Burlaud, 2015). The IASC released their first complete set of conceptual framework statements in 1989 and they were adopted as is by their successor, the International Accounting Standards Board (IASB) in 2001 (IFRS Foundation, 2015a).

Shortly after the establishment of the IASB, the FASB and the IASB decided to work towards converging the U.S. GAAP and the International Financial Reporting Standards (IFRS) with some focus on their respective conceptual frameworks (Lin, 2015). By 2011, both IASB and FASB had accomplished a good amount of convergence, but their individual focuses were distracted toward their own agendas instead of the overall goal, so the convergence project had slowed considerably. This prompted IASB to inquire of their standard users regarding where they should focus their efforts and the greatest response was to work on their conceptual framework (Rivera et al., 2014). The IASB released a discussion paper, A Review of the Conceptual Framework for Financial Reporting, in July 2013, to solicit feedback for development of their conceptual framework. They gathered 221 comment letters on the discussion paper and used those comments along with a series of meetings to develop the proposals within the Exposure Draft that is the topic of this research paper (Shang, 2015). The exposure draft is open for comment until November 25, 2015 and has amassed at least 217 comment letters from various sources around the world (IFRS Foundation, 2015b).

\section{Literature Review}

\subsection{Development of and Commitment to the Conceptual Framework}

While much of the history of accounting standards has been focused on bright-line rules and laws, such as the German Code of Commerce (Uwe Fulbier \& Klein, 2014) and the use of the static method of accounting (Baker \& Burlaud, 2015), most of the literature of today (JoA, 
2011; Baker \& Burlaud, 2015; Lin, 2015) has embraced the new notion of using a conceptual framework as a foundation for the development of accounting standards. After the FASB and IASB placed their convergence project on hold, the American Institute of Certified Public Accountants (AICPA) was one of many instrumental respondents in convincing the IASB that development of their conceptual framework was imperative (JoA, 2011). The AICPA mentioned that the fundamentals of the conceptual framework are needed to help guide the IASB in developing the IFRS, to fill in missing gaps within the standards for financial statement preparers, and reduce diversity in practice and interpretations (JoA, 2011).

Hans Hoogervorst, the IASB Chairman, made a vow in late 2012, after the move away from the convergence project with the FASB, that the IASB has been dysfunctional in delivering projects and that the new conceptual framework project will be handled completely by the IASB alone and will not miss the deadlines (Crump, 2012). At the time, the IASB had not worked on a major project such as this without input or help from an outside entity (i.e. FASB) and their standard users were deluging them with questions incessantly because of the lack of guidance (Crump, 2012). The conceptual framework project became the IASB's highest priority and is slated to be implemented in early 2016 (Crump, 2012; Tysiac, 2012). Unfortunately, Mr. Hoogervorst was also accused of denying the importance of prudence in the conceptual framework. Mr. Hoogervorst alluded that prudence was removed from the conceptual framework because the Americans did not like it and he also felt that prudence should support neutrality (IFRS Foundation, 2012). However, many feel that neutrality should not even be a concept because of all the judgements and estimates that are required in accounting (Wagenhofer, 2015). It will be interesting to see if and how the comment letters approach the issue of prudence.

\subsection{The Proposal}

The exposure draft itself is very comprehensive and covers eight separate chapters of the conceptual framework across more than 50 pages dedicated to those chapters (IFRS Foundation, 2015a). The exposure draft opens with a summary of the changes and why the IASB is proposing the changes along with 18 questions, some with multiple parts, which the IASB is asking interested parties to provide feedback (IFRS Foundation, 2015a). Overall the IASB states that the conceptual framework describes the objective of, and the concepts for, general purpose financial reporting (IFRS Foundation, 2015a). Each chapter provides new and updated information covered within the realm of each chapter topic (IFRS Foundation, 2015a). Chapter 1 is the springboard from which all other chapters are developed and is titled, "The objective of general purpose financial reporting" (IFRS Foundation, 2015a). Chapter 2, "Qualitative characteristics of useful financial information", builds upon Chapter 1's foundation and identifies the most relevant and useful information for financial statement users (IFRS Foundation, 2015a). Chapter 8 was previously Chapter 4 and is titled, "Concepts of capital and capital maintenance" (IFRS Foundation, 2015a). Chapters 3 through 7 are all new chapters and are titled according to the following list (IFRS Foundation, 2015a):

- Chapter 3 - Financial statements and the reporting entity;

- Chapter 4 - The elements of financial statements; 
- Chapter 5 - Recognition and derecognition;

- Chapter 6-Measurement;

- $\quad$ Chapter 7 - Presentation and disclosure (IFRS Foundation, 2015a).

\subsection{Basis for Conclusions and Alternative Views}

Although the exposure draft goes into great detail regarding the new and updated information, the explanations and reasons for each is neatly cataloged in a second document released with the exposure draft, the Basis for Conclusions. Each chapter in the exposure draft has paragraph numbers associated with various points within the text that link back to their respective paragraphs within the Basis for Conclusions document (IFRS Foundation, 2015c). These conclusions provide the respondents with the IASB considerations made while drafting the exposure draft and also more background, history, and scope of the project (IFRS Foundation, 2015c). The basis for conclusions give the respondents further insight and perspective into why the IASB developed the conceptual framework in the manner presented and because not all IASB board members agreed on all aspects, there is a section at the end of the basis for conclusions that presents the alternative views of specific items from the members that dissented against those areas (IFRS Foundation, 2015c). With both primary and alternative perspectives available to the respondents, the respondents will be able to answer the requested questions more effectively (IFRS Foundation, 2015c).

\subsection{Research Questions}

With many of the articles (JoA, 2011; Baker \& Burlaud, 2015; Lin, 2015) in agreement with the IASB's quest to develop a more solid foundation through the conceptual framework and only minor criticisms brought forth, the comment letters provided by various stakeholders to the May 2015 exposure draft are potentially the last line of influence on the IASB's final version. With that stated, the methodology that follows will endeavor to answer the following research questions:

(1) Does the IASB exposure draft proposal mirror the responses received from the 217 respondents?

(2) How do the 217 respondents relate to the alternative views presented by the dissenters?

\section{Methodology of Research}

\subsection{Research Data Source}

The research data is derived from the 217 comment letters submitted to the IASB (IFRS Foundation, 2015b) in response to their call for comments on the exposure draft (IFRS Foundation, 2015a). The IASB invited respondents to comment on any of the 18 questions posed and respondents were only encouraged to answer on questions that they felt required their response or any additional matters as well (IFRS Foundation, 2015a). The answers provided within the comment letters were tabulated and those results were analytically discussed and correlated to the IASB's proposals and alternative views as published in the exposure draft, ED/2015/3 (IFRS Foundation, 2015a), and the basis for conclusions (IFRS 


\section{MInstitute Macrothink $^{\text {Int }}$}

World Journal of Business and Management

ISSN 2377-4622

2016, Vol. 2, No. 1

Foundation, 2015c). The 18 questions posed to respondents are summarized in list format and are located in Appendix A.

\subsection{Research Sample Size}

Due to the number of comment letters, the research sample was pared down to 72 of the 217 comment letters that acknowledged and answered all 18 Exposure Draft questions. These 72 comment letters did provide, at the very least, an answer of 'no comment' on each question. The list of comment letters with coded number, respondent name, and respondent organization, if any, can be found in Appendix B.

\subsection{Exposure Draft Questions Tabulated}

Out of the 18 questions, only 15 questions require tabulation because question numbers 5, 11, and 18 are open-ended questions asking for broad comments on their respective areas. Question numbers 1, 2, 3, and 8 are multi-point questions and each point was tabulated as an individual question. The 32 alternative views posed at the end of the Basis for Conclusions document (IFRS Foundation, 2015c) were combined and categorized under 5 separate categories that were based on exposure draft sections and the questions posed within those sections (see Table 5 notes for details). The tabulation of agree and disagree, for both the exposure draft questions and the potential agreement with the alternative views, was subjective in some situations when the respondents did not provide a definitive or direct agree or disagree position on the issue at hand. Overtly positive responses to the proposals were tabulated as if they disagreed to the alternative views. The tables for both the questions and the alternative views are located in the Tables section after the references.

\subsection{Research Hypotheses}

Based on the research questions posed earlier and the tabulation of the responses made within the comment letters, the following hypotheses can be tested:

1. If the proposed Conceptual Framework for Financial Reporting can enhance the IASB's standard-setting process and help alleviate interpretive slack within the standards, the majority of respondents will agree with the proposals presented within the Exposure Draft.

2. If members of the IASB disagree with portions of the proposal, considered the alternative views, a large number of the respondents will also disagree with portions of the proposal and agree with those alternative views.

\section{Data Analysis and Interpretation}

\subsection{Results}

\subsubsection{IASB Proposals}

Overall the results show strong support, $66 \%$, for the IASB proposals to the Conceptual Framework (see Table 1). This is a promising outlook for the IASB's proposals for the Conceptual Framework, but they still have their work cut out for them. Each question had a positive response of at least $56 \%$, with the exception of questions $2 \mathrm{~b}, 12,13$, and 14 which 
accumulated $53 \%, 51 \%, 75 \%$, and $65 \%$ of disagreement respectively (see Table 3 and Table 4).

Table 1. Analysis of comment letters - totals

\begin{tabular}{|c|c|c|}
\hline Measure & Number & Percentage \\
\hline Agree (A) & 1193 & $66 \%$ \\
\hline Disagree (D) & 511 & $29 \%$ \\
\hline No Comment (N) & 96 & $5 \%$ \\
\hline
\end{tabular}

\subsubsection{Alternative Views}

With regard to the comparison of the alternative views to the suggestions or comments made by the 72 respondents, a majority, 58\%, did not make suggestions or comments that supported the alternative views and $41 \%$ supported some of the alternative views (see Table 2). The alternative views regarding other comprehensive income, the profit and loss statement, and recycling showed the highest agreement with $90 \%$ of the respondents making comments or suggestions in their comment letters that was in-line with those particular alternative views (see Table 5).

Table 2. Analysis of alternative views - totals

\begin{tabular}{|c|c|c|}
\hline Measure & Number & Percentage \\
\hline Agree (A) & 146 & $41 \%$ \\
\hline Disagree (D) & 209 & $58 \%$ \\
\hline No Comment (N) & 5 & $1 \%$ \\
\hline
\end{tabular}

\subsection{Discussion}

\subsubsection{Question 1a - Management's Stewardship of the Entity's Resources}

There is overwhelming support, 90\%, for the proposal to provide stewardship more prominence in the Conceptual Framework (Table 3). The respondents that disagreed provided reasons such as the proposal shifts too much focus from all capital providers to shareholders only (Barckow, 2015; Owais, 2015), it is not clear how the financial statements can reflect stewardship (Alves, 2015), and stewardship should be defined before acceptance of the proposal can happen (Fleming, 2015; Pinnarwan, 2015). Also while Liz Murral of The Investment Association (Murral, 2015) believes that stewardship should be considered as a separate objective of financial reporting, Emilio Linares-Rivas of REPSOL (Linares-Rivas, 2015) believes that it is already implicit in the current objectives and should be removed. 


\subsubsection{Question 1b - Reintroduction of Prudence}

Many respondents, $68 \%$, agree with the reintroduction of the concept of prudence into the Conceptual Framework (Table 3). The main justification provided by the dissenters is that prudence does not support the notion of neutrality as proposed and will most likely create more confusion or encourage earnings management (Hellman, 2015; Martin, 2015; Nixon, 2015; Ratshitanga, 2015). This dissenting perspective coincides with the high percentage, $47 \%$, of respondents that agree with IASB Board Member, Mr. Patrick Finnegan's alternative view (AV16 - Table 5) regarding prudence (IFRS Foundation, 2015c).

\subsubsection{Question 1c - Substance over Form}

This topic has garnered substantial support with $92 \%$ in agreement (Table 3). The two respondents that do not agree both agree that substance over form is a better characteristic of relevance rather than faithful representation (Hong, 2015; Wijesingha, 2015).

\subsubsection{Question 1d - Measurement Uncertainty}

There is a large amount of support for this topic at $71 \%$ (Table 3). The concern that was voiced by many of the dissenters was that measurement uncertainty should not be a factor of relevance, but rather a factor of faithful representation (Debell, 2015; Otaka, 2015) or even a factor of both relevance and faithful representation (Bucquet, 2015).

\subsubsection{Question 1e - Relevance and Faithful Representation}

At $81 \%$, this proposal has been endorsed heavily (Table 3). Among many of the supporters and opponents to this topic, there is a suggestion that 'reliability' should be added back into these characteristics along with the other two characteristics of relevance and faithful representation (Hutchinson, 2015; Michel, 2015) or used in place of faithful representation (Machenil, 2015). Another respondent (Green, 2015) also suggested that the characteristic of 'transparency' should be included as well.

\subsubsection{Question 2a - Reporting Entity Description}

The first part of question two has 78\% advocacy from the respondents (Table 3). There are a few reasons provided from the dissenters of why they do not agree with the description of a reporting entity. These reasons include the lack of a clear definition of 'reporting entity' (Martin, 2015; Stylianou, 2015), the definition does not provide a conceptual element and is too concrete (Hellman, 2015), and there is no specific definition for 'entity' or 'legal entity' which are used within the Conceptual Framework (Fleming, 2015).

\subsubsection{Question $2 b$ - Boundary of a Reporting Entity}

This is the first question that more respondents disagree, 53\%, with the proposals versus agree (Table 3). A majority of the comments made regarding this topic, no matter if the respondents agreed or disagreed, was that this section was unclear with respect to direct/indirect control and how control, as defined in this section, interacts with other uses of the word control throughout the various proposals (Bildstein-Hagberg, 2015; Crook, 2015). There were two respondents that perceived the boundary of the reporting entity as being 
controlled by the local regulations and laws within the entity's jurisdiction and should be eliminated from the Conceptual Framework (Bodi, 2015; Schneider, 2015). In addition, there was one other theme that resonated with many of the dissenters, the IASB should not place consolidated financial statements at a higher degree of usefulness than unconsolidated financial statements, they should be equal (Bildstein-Hagberg, 2015; Stachniak, 2015; Burbi, 2015).

\subsubsection{Question 3a - Definition of an Asset and Economic Resource}

These two definitions have acquired a decent amount, 75\%, of agreement (Table 3). Many of the respondents that disagree were concerned with the use of the word 'present' in the definition and thought this might cause confusion (i.e. current assets), especially when translated to other languages (Collinge, 2015; Nixon, 2015). Another issue brought to light is that the new definition of asset does not fit with the guidance in the current standards and should not have been changed (Bodi, 2015; Corbi, 2015). Also some feel that turning the focus of assets toward economic resources, which are defined as 'rights', may make the definition too complex and potentially lose clarity (Hodgkiss, 2015; Kvaal, 2015).

\subsubsection{Question 3b - Definition of Liability}

Although there is decent support for the definition of a liability, 68\%, the opposition has a generous number of followers as well at $29 \%$ (Table 3). As with the asset definition in Question 3a, the inclusion of the word 'present' may cause confusion (Nixon, 2015) and coincides with some issues that have been found in the 'present obligation' section of the Exposure Draft (see Question 4) (Barckow, 2015; Bucquet, 2015). The main issue suggested is that the definition of a liability is tied too closely together with equity (Question 3c) to provide a clear definition without tackling and finishing the proposed research in the IASB's project, "Financial Instruments with Characteristics of Equity" (FICE), as this would allow the issue between liabilities and equity to be settled more thoroughly and provide the means to be able to finalize the definition of a liability (Machenil, 2015; Buggle, 2015; Curtis, 2015).

\subsubsection{Question 3c - Definition of Equity}

As with a liability, the approval of this definition is reasonably supported at $67 \%$ (Table 3). Even though it has a high approval percentage, many of the supporters and opponents agree that the FICE project must be completed before a solid definition can be made for both a liability and equity (Machenil, 2015; Buggle, 2015; Curtis, 2015; Causevic, 2015; Montalvo, 2015). This view is also reiterated in the IASB Board Members, Ms. Suzanne Lloyd's and Mr. Patrick Finnegan's, alternative views, AV8 through AV14 (IFRS Foundation, 2015c), of which $30 \%$ of the respondents agree with their perspective (Table 5).

\subsubsection{Question 3d and 3e - Definition of Income and Expenses}

The topic of income only garnered $61 \%$ agreement (Table 3 ). The topic of expenses garnered almost identical numbers except for a single respondent that disagreed with the definition of income, but agreed with the topic of expenses, which pushed expenses up to $63 \%$ agreement 
(Table 3). There are two camps within the dissenters that are similar, but a bit different. The first camp believes that defining 'income' as an increase in assets or decrease in liabilities and 'expenses' as a decrease in assets or increase in liabilities is incorrect and should be an increase/decrease in equity respectively (Collinge, 2015; Green, 2015; Hellman, 2015). The single respondent that agreed with the definition of expenses also agrees that equity increases should be the measurement used for 'income' (Omona, 2015). The second camp believes that defining 'income' and 'expenses' as an increase/decrease in assets or a decrease/increase in liabilities puts too much emphasis on the statement of financial position, but equal emphasis should be placed on the statement of financial position and the statement of financial performance (Fleming, 2015; Murrall, 2015; Williams, 2015).

\subsubsection{Question 4 - Present Obligation}

The tabulated results for this topic follow closely with that of Question $3 b$ - Definition of a liability because the concepts for both are intertwined. There is quite a large amount of support for this proposal at $67 \%$ (Table 3). The main issue presented by respondents is that the concepts of 'no practical ability to avoid the transfer' and 'economic compulsion' must be clarified further (Bucquet, 2015; Curtis, 2015; Yoo, 2015). There is also an issue suggested that the concept of constructive obligations should be added into the Conceptual Framework as well to help revise the criterion used to assess the entity's ability to avoid the transfer (Takahashi, 2015). It is also mentioned that if the phrase, 'as a result of past events' is defined here for present obligations, then there should be no mention of past events in the definition for a liability (Ingall, 2015).

\subsubsection{Question 6 - Recognition Criteria}

This proposal accumulated 69\% approval and 26\% disapproval (Table 4). The main concern posed by the opposition is that the recognition criteria from the old framework are more intuitive and would request that the reference to the probability criterion be reinstated (Chen, 2015; Michel, 2015; Wesolowski, 2015).

\subsubsection{Question 7 - Derecognition}

There is significant agreement with this proposal, $81 \%$ (Table 4). The major suggestions from the respondents include providing criteria in derecognition that mirrors that of recognition (Berggren, 2015; Hong, 2015; Mitchell, 2015) or remove derecognition as a separate concept and ensure the recognition criteria is robust enough to allow derecognition if the asset/liability no longer meets the recognition criteria (Fleming, 2015; Whitfield, 2015).

\subsubsection{Question 8a - Identified the Measurement Bases}

$76 \%$ of the respondents agree that the IASB has identified the measurement bases that should be described in the Conceptual Framework (Table 4). Opposition to this proposal suggests that 'historical cost' and 'current value' are not intuitive enough to be the two broad categories that other potentially more complex measurement bases will be used to establish and they feel that a better set of categories may be 'entry values' and 'exit values' (Buggle, 2015; Green, 2015; Otaka, 2015). There is also some discussion from respondents that the 
entire measurement chapter (Chapter 6) is not conceptual enough because it just lists what is used in practice currently and does not provide an overarching objective of measurement (Crook, 2015; Mitchell, 2015).

\subsubsection{Question 8b - Described the Measurement Bases}

This proposal topic received $74 \%$ agreement and $21 \%$ disagreement (Table 4). The issues proposed by a majority of the opposition reflect exactly the same sentiments as question 8a. In regards to Mr. Patrick Finnegan's alternative views (AV17-AV22 \& AV27-AV28 - Table 5), only $21 \%$ of the respondents agree with some of his views.

\subsubsection{Question 9-Selecting a Measurement Basis}

Only $63 \%$ agree with the IASB's factors for selecting a measurement basis (Table 4). Many respondents believe that this section of the Conceptual Framework is not complete and requires more guidance (Bildstein-Hagberg, 2015; Causevic, 2015; Murrall, 2015). There is also a push to include business activities/business model as a factor for selecting a measurement basis (Fleming, 2015; Machenil, 2015) and to provide some form of hierarchy for the factors to distinguish stronger factors from the others (Barckow, 2015; Owais, 2015). With regards to Mr. Patrick Finnegan's alternative views (AV23-AV26 - Table 5), only 14\% of the respondents agree with some of his views.

\subsubsection{Question 10 - More than One Measurement Basis}

Even though this proposal has garnered $72 \%$ approval, the $27 \%$ of divergent respondents bring up a few good points (Table 4). The first point challenges the thought that if more than one measurement basis is being used for different financial statements, then the information become irrelevant and could confuse users (Crook, 2015; Curtis, 2015; Green, 2015). The second point is that the use of the word 'sometimes' may cause confusion and there should be more precise guidance on when more than one measurement basis should be and should not be used (Barckow, 2015; Buggle, 2015). The third point made is that this concept should not be considered at the conceptual level, but rather the standards level (Richardt, 2015; Whitfield, 2015).

\subsubsection{Question 12 - Description of the Statement of Profit or Loss}

This question along with questions 13 and 14 come from Chapter 7 - Presentation and Disclosure, which is highly contested by the respondents, but this question is fairly divided among agreement and disagreement with $51 \%$ disagree and $49 \%$ agree (Table 4). Most respondents agree that the description of the statement of profit or loss is good, but many believe that the IASB must go further and provide a definition as well (Chen, 2015; Buchanan, 2015; Gomes, 2015). There are many that also suggest that a definition of 'financial performance' would help as well (Chitty, 2015; Crook, 2015; Nixon, 2015), which also puts many respondents in agreement, 90\%, with IASB Board Members, Mr. Stephen Cooper's and Mr. Patrick Finnegan's, alternative views (AV2-AV7 \& AV29-AV33 - Table 5). 


\subsubsection{Question 13 - Use of Other Comprehensive Income}

This question has the highest percentage of disagreement, 75\%, among all the questions from the exposure draft (Table 4). Much of the dissent exists with the facts that 'other comprehensive income' (OCI) has not been defined (Berggren, 2015; Cervantes, 2015a) and justified reasons at the conceptual level for the use of OCI has not been provided (Burbi, 2015; Ng, 2015). There is also a call for more distinction between the statement of profit or loss and the statement of other comprehensive income (Chopping, 2015). The respondents also heavily agree, $90 \%$, with the alternative views of Mr. Stephen Cooper and Mr. Patrick Finnegan in respect to OCI (AV2-AV7 \& AV29-AV33 - Table 5).

\subsubsection{Question 14 - Rebuttable Presumption to Recycling}

The idea of recycling has received favorable reviews, but adding in a rebuttable presumption to recycling has met with a high degree of disagreement at $65 \%$ (Table 4). This also resonates well with Mr. Stephen Cooper's and Mr. Patrick Finnegan's alternative views (AV2-AV7 \& AV29-AV33 - Table 5) with a huge percentage of respondents agreeing with them at $90 \%$ (Table 5).

\subsubsection{Question 15 - Effects of Proposed Changes}

Although many of the respondents agreed, 56\% (Table 4), with the IASB's assessment of the effects of proposed changes that the proposal would make to the Conceptual Framework, many believe that the IASB must take extra measures to eliminate inconsistencies between the Conceptual Framework and the current standards due to the confusion that it could create once the Conceptual Framework is released (Buggle, 2015; Cervantes, 2015b; Hodgkiss, 2015).

\subsubsection{Question 16 - Business Activities}

With $61 \%$ approval, this proposal has convinced many respondents that the approach to business activities is beneficial to the Conceptual Framework (Table 4). However, many respondent think that the term 'business model' is more appropriate than 'business activities' because 'business model' is already used in at least one standard (Nixon, 2015; Ogloza, 2015, Saeglitz, 2015). There was one other respondent that suggested that accounting treatment should always reflect the substance of the transaction rather than reflect the business activities of a particular entity (Grigg, 2015).

\subsubsection{Question 17 - Long-Term Investment}

The final tabulated question garnered $78 \%$ agreement with the IASB's conclusions regarding long-term investment (Table 4). The vocal minority's response is basically that if the financial statements are providing the information required from current and potential investors, then the horizon of investment is irrelevant and this proposal should not be part of the Conceptual Framework (Bodi, 2015; Collinge, 2015; Michel, 2015). A second perspective suggests that this level of detail should be handled at the standards level and not the Conceptual Framework level (Berggren, 2015; Montalvo, 2015; Ratshitanga, 2015). 


\subsection{Hypothesis Analysis}

\subsubsection{Hypothesis 1}

With $66 \%$ of the responses positive towards the proposed Conceptual Framework, the hypothesis has been supported (Table 3). However, there are still many facets of the proposal that need to be deliberated and potentially fleshed-out before the IASB should release the updated framework as is pointed out by the $29 \%$ of disapproval (Table 3 ). There is a plethora of information that the IASB must digest before deliberations, not only from the 72 comment letters used to tabulate the results for this research, but from all the comment letters that were submitted. It will certainly be a monumental task for the IASB to achieve the release of the updated Conceptual Framework in early 2016.

\subsubsection{Hypothesis 2}

The alternative views of IASB Board Members, Mr. Stephen Cooper, Ms. Suzanne Lloyd, and Mr. Patrick Finnegan, provide the respondents with a different perspective on specific areas of the proposals. This usually promotes more thought and discussion because there are diverging views on some subjects and due to the tabulations showing that $41 \%$ of the responses (Table 5) in those areas agree with the alternative views presented, the second hypothesis is also supported. A majority of the supporters for the alternative views were entrenched in the topics of prudence and other comprehensive income. Many of the suggestions brought forth in these areas will hopefully assist the IASB in deriving an appropriate concept for those areas even though a majority of the IASB board has already shown that they are opposed to these ideas.

\subsection{Further Research}

The final question that was asked of respondents in the Exposure Draft was, "Do you have any comments on any other aspect of the Exposure Draft?", and the Exposure Draft also specified that the International Accounting Standards Board (IASB) was not requesting comments at all on Chapter 8, "Concepts of Capital and Capital Maintenance", but many respondents made a point to discuss this chapter specifically. The major points introduced by these respondents includes: (1) the content of Chapter 8 should not have been carried forward from the old framework, (2) it is outdated information, (3) does not fit with the other chapters of the Conceptual Framework, (4) concepts are strictly relevant to hyperinflationary economies, and (5) is not linked to any other chapters in the Conceptual Framework. Almost all respondents agree that Chapter 8 should be at the very least rewritten, but to achieve a near-future release of the Conceptual Framework, they also agree that this chapter should be eliminated from the current Conceptual Framework and reconsidered at a later date. Further research could be conducted to determine the IASB's final decision regarding Chapter 8 after release of the Conceptual Framework and how their future plans for Chapter 8 fit within their constituents' perspectives. How does the IASB view Chapter 8 after reviewing and deliberating the comment letters provided to the Exposure Draft ED/2015/3?

Question 13 of the Exposure Draft pertains to the use of other comprehensive income (OCI) and $75 \%$ of respondents disagreed (Table 4) with the IASB's proposals. The main issue from 
these respondents was in regards to the lack of definition of OCI or OCI items anywhere in the framework. They also agree that there is a lack of principles underlying the use of OCI for preparers and users to follow. Further research could be made into the current comment letter suggestions and potentially how the IASB interprets these suggestions before releasing the Conceptual Framework. What are some of the suggestions brought forward by the respondents to ED/2015/3 regarding other comprehensive income and how will the IASB react to these suggestions?

Although the proposal for reintroduction of prudence got positive reviews, 68\% (Table 3), almost every respondent requests the IASB further develop the definition of prudence so there is less confusion in the meaning and interpretation. The respondents also would like the IASB to recognize asymmetric prudence within the Conceptual Framework instead of just cautious prudence because some of the existing standards already reflect asymmetric prudence. Further research could be performed to determine the best definition of prudence and potentially assist the IASB with defining prudence within the Conceptual Framework for future exposure drafts and deliberations. What is the best definition for prudence and how can the IASB reflect this perspective within the Conceptual Framework?

\section{Conclusion}

The IASB issued the exposure draft, ED/2015/3, regarding updates to the Conceptual Framework for Financial Reporting to solicit responses from the general public and received an overwhelming response of at least 217 comment letters. Based on the information collected and tabulated for this research, the majority of respondents agree with the proposed updates. There are a few exceptions that the respondents did not agree with which includes the reintroduction of prudence, the definition of the statement of profit or loss, the definition and use of the statement of other comprehensive income, and the inclusion of a rebuttable presumption for recycling of assets/liabilities back into the statement of profit or loss. The alternative views were also important to the process so that the respondents had more perspectives to view the proposals and deliberate amongst themselves to derive their answers and suggestions to the exposure draft. The respondents hope that their contribution to the project will help the IASB develop a strong and thorough Conceptual Framework to make the job of creating standards easier and provide users with further understanding.

\section{References}

Alves, P. J. (2015). Comment letter to ED/2015/3. Retrieved from http://eifrs.ifrs.org/eifrs/comment_letters/50/50_5824_PauloJosAlvesPETROBRAS_0_CL_P ETROBRAS_Framework.pdf

Baker, C. R., \& A. Burlaud. (2015, August). The historical evolution from accounting theory to conceptual framework in financial standards setting. The CPA Journal, 85(8), 54-60. Retrieved from https://www.nysscpa.org/news/publications/the-cpa-journal/article-detail?ArticleID=11623

Barckow, A. (2015). Comment letter to ED/2015/3. Retrieved from http://eifrs.ifrs.org/eifrs/comment_letters/50/50_5723_AndreasBarckowASCG_0_151124_C 
L_ASCG_IASB_ED_CF_20153.pdf

Berggren, E. (2015). Comment letter to ED/2015/3. Retrieved from http://eifrs.ifrs.org/eifrs/comment_letters/50/50_5901_ErikBerggrenBUSINESSEUROPE_0_ 11127iasbconceptualframework.pdf

Bildstein-Hagberg, S. (2015). Comment letter to ED/2015/3. Retrieved from http://eifrs.ifrs.org/eifrs/comment_letters/50/50_5866_SimonIngallShellInternationalLtd_0_E D2015ConceptualFramework.pdf

Bodi, M. S. (2015). Comment letter to ED/2015/3. Retrieved from http://eifrs.ifrs.org/eifrs/comment_letters/50/50_5968_MartaSotoBodiTelefonicaSA_0_Com mentletterED2015_3andED2015_4TEF.pdf

Buchanan, A. (2015). Comment letter to ED/2015/3. Retrieved from http://eifrs.ifrs.org/eifrs/comment_letters/50/50_5887_AndrewBuchananBDO_0_BDOCLED 20153ConceptualFramework.pdf

Bucquet, D. (2015). Comment letter to ED/2015/3. Retrieved from http://eifrs.ifrs.org/eifrs/comment_letters/50/50_5727_DorotheeBucquetIIF_0_IIFresponselet terEDConceptualFramework112015.pdf

Buggle, S. (2015). Comment letter to ED/2015/3. Retrieved from http://eifrs.ifrs.org/eifrs/comment_letters/50/50_5756_ShaneBuggleAustraliaandNewZealand BankingGroupLimited_0_IASBHHoogervorstFINAL251115.pdf

Burbi, D. (2015). Comment letter to ED/2015/3. Retrieved from http://eifrs.ifrs.org/eifrs/comment_letters/50/50_5905_DavidBurbiCNCLuxembourg_0_GT4 CL00115CNCLUcommentletteronED20153ConceptualFrameworkforFinancialReporting.pdf

Causevic, M. (2015). Comment letter to ED/2015/3. Retrieved from http://eifrs.ifrs.org/eifrs/comment_letters/50/50_5858_MarkCausevicInternationalAssociation ofInsuranceSupervisorsIAIS_0_151125IAIScommentletteronIASBConceptualFramewordED. pdf

Cervantes, F. P. (2015a). Comment letter to ED/2015/3. Retrieved from http://eifrs.ifrs.org/eifrs/comment_letters/50/50_5829_FelipePrezCervantesCINIF_0_CINIFc ommentsonED20153ConceptualFramework.pdf

Cervantes, F. P. (2015b). Comment letter to ED/2015/3. Retrieved from http://eifrs.ifrs.org/eifrs/comment_letters/50/50_5830_FelipePrezCervantesGLASS_0_GLAS SCommentletteronConceptualFramework.pdf

Chen, L. (2015). Comment letter to ED/2015/3. Retrieved from http://eifrs.ifrs.org/eifrs/comment_letters/50/50_5749_LibingChen_0_commentlettertoIASB. docx

Chitty, D. (2015). Comment letter to ED/2015/3. Retrieved from http://eifrs.ifrs.org/eifrs/comment_letters/50/50_5891_DavidChittyCroweHorwathInternation 
al_0_51_5752_DavidChittyCroweHorwathInternational_0_CroweHorwathCommentLetterCo nceptualFramework251115.pdf

Chopping, D. (2015). Comment letter to ED/2015/3. Retrieved from http://eifrs.ifrs.org/eifrs/comment_letters/50/50_5811_DavidChoppingMooreStephensLLP_0 _MooreStephensresponse251115.pdf

Collinge, R. (2015). Comment letter to ED/2015/3. Retrieved from http://eifrs.ifrs.org/eifrs/comment_letters/50/50_5868_RogerCollingeUKShareholdersAssocia tionUKSA_0_CL53UKSAresponsetotheCFEDNov2015.pdf

Corbi, A. (2015). Comment letter to ED/2015/3. Retrieved from http://eifrs.ifrs.org/eifrs/comment_letters/50/50_5769_AntonioCorbiISDA_0_ISDACF25112 015final.pdf

Crook, K. (2015). Comment letter to ED/2015/3. Retrieved from http://eifrs.ifrs.org/eifrs/comment_letters/50/50_5683_KimberleyCrookNewZealandAccounti ngStandardsBoardNZASB_0_50_5676_KimberleyCrookNZASB_0_NZASBCommentLetter ED20153ED20154ConceptualFrameworkforFinancialReporting.pdf

Crump, R. (2012, October 21). Hoogervorst gets tough over IASB framework deadline. Accountancy Age. Retrieved from http://www.accountancyage.com/aa/analysis/2218655/hoogervorst-gets-tough-over-framewor k-deadline

Curtis, A. (2015). Comment letter to ED/2015/3. Retrieved from http://eifrs.ifrs.org/eifrs/comment_letters/50/50_5753_AsherCurtisFRPCFARSAAA_0_Com ment_letter_draft_20151124.pdf

Debell, T. (2015). Comment letter to ED/2015/3. Retrieved from http://eifrs.ifrs.org/eifrs/comment_letters/50/50_5823_TonyDebellPwC_0_ConceptualFrame workforFinancialReportingPwCresponse25Nov2015.pdf

Deloitte. (2015). About the International Accounting Standards Committee (IASC). Retrieved from http://www.iasplus.com/en/resources/ifrsf/history/resource25

Fleming, C. (2015). Comment letter to ED/2015/3. Retrieved from http://eifrs.ifrs.org/eifrs/comment_letters/50/50_5879_ColinFlemingDeloitteToucheTohmatsu LimitedDTTLUK_0_DTTLCommentLetter_ED201503.pdf

Gomes, M. (2015). Comment letter to ED/2015/3. Retrieved from http://eifrs.ifrs.org/eifrs/comment_letters/50/50_5826_MicheleGomesBradesco_0_Conceptua 1Framework.pdf

Green, B. S. (2015). Comment letter to ED/2015/3. Retrieved from http://eifrs.ifrs.org/eifrs/comment_letters/50/50_5666_BrianSingletonGreenTheInstituteofCh arteredAccountantsinEnglandandWalesICAEW_0_ICAEWRep15415IASBConceptualFrame workforFinancialReporting.pdf 
Grigg, L. (2015). Comment letter to ED/2015/3. Retrieved from http://eifrs.ifrs.org/eifrs/comment_letters/50/50_5636_LynGriggTheHeadsofTreasuriesAccou ntingandReportingAdvisoryCommitteeHoTARAC_0_HoTARACsubmisssiontoIASBED2015 3 conceptualframework.pdf

Hellman, N. (2015). Comment letter to ED/2015/3. Retrieved from http://eifrs.ifrs.org/eifrs/comment_letters/50/50_5627_NiclasHellmanEuropeanAccountingAs sociation_0_EAAcommentletterCFED.pdf

Hodgkiss, G. (2015). Comment letter to ED/2015/3. Retrieved from http://eifrs.ifrs.org/eifrs/comment_letters/50/50_5774_GregoryHodgkissACTEOAFEPMEDE F_0_GregoryHodgkisACTEOAEFEPMEdef.pdf

Hong, H. S. (2015). Comment letter to ED/2015/3. Retrieved from http://eifrs.ifrs.org/eifrs/comment_letters/50/50_5885_HyunSeonHongKASB_0_KASBResp onsetoIASBEDCFQuestion.pdf

Hutchinson, A. (2015). Comment letter to ED/ 2015/3. Retrieved from http://eifrs.ifrs.org/eifrs/comment_letters/50/50_5806_AmyHutchinsonTheInstituteofChartere dAccountantsofScotlandICAS_0_20151125ResponsetoIASBEDConceptualFrameworkFINA L.pdf

Ingall, S. (2015). Comment letter to ED/2015/3. Retrieved from http://eifrs.ifrs.org/eifrs/comment_letters/50/50_5866_SimonIngallShellInternationalLtd_0_E D2015ConceptualFramework.pdf

International Charted Accountants of Scotland (ICAS). (2015). Who we are. Retrieved from https://www.icas.com/about-icas/who-we-are

International Financial Reporting Standards (IFRS) Foundation. (2012). The concept of prudence: Dead or alive? Retrieved from http://www.ifrs.org/Alerts/PressRelease/Documents/2012/Concept\%20of\%20Prudence\%20sp eech.pdf

IFRS Foundation. (2015a). Exposure Draft: Conceptual Framework for Financial Reporting. Retrieved from http://www.ifrs.org/Current-Projects/IASB-Projects/Conceptual-Framework/Documents/May \%202015/ED_CF_MAY\%202015.pdf

IFRS Foundation. (2015b). Conceptual framework: Comment letters. Retrieved from http://www.ifrs.org/Current-Projects/IASB-Projects/Conceptual-Framework/Pages/Commentletters.aspx

IFRS Foundation. (2015c). Basis for Conclusions: Conceptual Framework for Financial Reporting. Retrieved from http://www.ifrs.org/Current-Projects/IASB-Projects/Conceptual-Framework/Documents/May \%202015/Basis-to-ED_CF_MAY\%202015.pdf

Journal of Accountancy (JoA). (2011, December 1). AICPA to IASB: Completion of 
conceptual

framework

key.

Retrieved

from

http://www.journalofaccountancy.com/news/2011/dec/20114841.html

Kvaal, E. (2015). Comment letter to ED/2015/3. Retrieved from http://eifrs.ifrs.org/eifrs/comment_letters/50/50_5840_ErlendKvaalNorskRegnskapsStiftelse NASBNorwegianAccountingStandardsBoard_0_56_5801_ErlendKvaalNorskRegnskapsstifte 1seNorwegianAccountingStandardsBoard_0_20151125ED20153Framework.pdf

Lin, H. 2015. Discussion about conceptual framework. International Business Research, 8(6), 191-195. Retrieved from http://dx.doi.org/10.5539/ibr.v8n6p191

Linares-Rivas, E. (2015). Comment letter to ED/2015/3. Retrieved from http://eifrs.ifrs.org/eifrs/comment_letters/50/50_5838_EmilioLinaresRivasREPSOL_0_Repso 1_CL_ED_2015_3ConceptualFramework.pdf

Machenil, L. (2015). Comment letter to ED/2015/3. Retrieved from http://eifrs.ifrs.org/eifrs/comment_letters/50/50_5882_LarsMachenilBNPPARIBAS_0_IASB BNPP_CL_ED_ConceptualFramework20151125v11envoiLM.pdf

Martin, R. (2015). Comment letter to ED/2015/3. Retrieved from http://eifrs.ifrs.org/eifrs/comment_letters/50/50_5817_RichardMartinACCA_0_conceptualFr ameworkResp1115.docx

Michel, B. M. (2015). Comment letter to ED/2015/3. Retrieved from http://eifrs.ifrs.org/eifrs/comment_letters/50/50_5941_BARBETMASSINMICHELMAZARS _0_MazarsCommentLetterED20153ConceptualFrameworkforFinancialReporting.pdf

Mitchell, N. (2015). Comment letter to ED/2015/3. Retrieved from http://eifrs.ifrs.org/eifrs/comment_letters/50/50_5464_NevilleMitchellGroupof100IncAustrali a_0_TheGroupof100Incorporated.pdf

Montalvo, C. (2015). Comment letter to ED/2015/3. Retrieved from http://eifrs.ifrs.org/eifrs/comment_letters/50/50_5789_CarlosMontalvoEuropeanInsuranceand OccupationalPensionsAuthorityEIOPA_0_CommentConceptualFrameworkEIOPA.pdf

Murrall, L. (2015). Comment letter to ED/2015/3. Retrieved from http://eifrs.ifrs.org/eifrs/comment_letters/50/50_5731_LizMurrallTheInvestmentAssociation_ 0_ConceptualFrameworkEDfinal.pdf

$\mathrm{Ng}$, C. (2015). Comment letter to ED/2015/3. Retrieved from http://eifrs.ifrs.org/eifrs/comment_letters/50/50_5974_ChristinaNgHKICPA_0_ConceptualFr ameworkforFinancialReporting_final.pdf

Nixon, O. (2015). Comment letter to ED/2015/3. Retrieved from http://eifrs.ifrs.org/eifrs/comment_letters/50/50_5785_OmindiNixonInstituteofCertifiedPubli cAccountantsofKenyaICPAK_0_50_5760_OmindiNixonInstituteofCertifiedPublicAccountan tsofKenyaICPAK_0_ExposureDraftED20153ConceptualFrameworkforFinancialReporting.pd $\mathrm{f}$ 
Ogloza, D. (2015). Comment letter to ED/2015/3. Retrieved from http://eifrs.ifrs.org/eifrs/comment_letters/50/50_5681_DavidOglozaInsuranceEurope_0_50_5 674_DavidOglozaInsuranceEurope_0_InsuranceEuropecommentsontheConceptualFramewor kED.pdf

Omona, M. (2015). Comment letter to ED/2015/3. Retrieved from http://eifrs.ifrs.org/eifrs/comment_letters/50/50_5954_MarkOmonaInstituteofCertifiedPublic AccountantsofUganda_0_ConceptualFrameworkExposureDraftICPAUComments.pdf

Otaka, M. (2015). Comment letter to ED/2015/3. Retrieved from http://eifrs.ifrs.org/eifrs/comment_letters/50/50_5909_makotootakaASBJ_1_ASBJComment ontheIASBsExposureDraftConceptualFrameworkforFinancialReporting_nocopyprotection.pd $\mathrm{f}$

Owais, M. (2015). Comment letter to ED/2015/3. Retrieved from http://eifrs.ifrs.org/eifrs/comment_letters/50/50_5770_MuhammadOwaisInstituteofChartered AccountantsofPakistan_0_ICAPCommentsonEDCF.pdf

Pinnarwan, D. (2015). Comment letter to ED/2015/3. Retrieved from http://eifrs.ifrs.org/eifrs/comment_letters/50/50_5956_DjohanPinnarwanTheIndonesianFinan cialAccountingStandardsBoardDSAKIAI_0_DSAKIAI_ED201503_ConceptualFramework.p df

Ratshitanga, M. (2015). Comment letter to ED/2015/3. Retrieved from http://eifrs.ifrs.org/eifrs/comment_letters/50/50_5757_MulalaRatshitangaSAICA_0_SAICA_ SUBMISSION_ON_ED_2015_3_CONCEPTUAL_FRAMEWORK_FOR_FINANCIAL_R EPORTING_AND_ED_2015_4_UPDATING_REFERENCES_TO_THE_CONCEPTUAL_ FRAMEWORK_PR.pdf

Richardt, B. (2015). Comment letter to ED/2015/3. Retrieved from http://eifrs.ifrs.org/eifrs/comment_letters/50/50_5855_BodoRichardtEuropeanFederationofAc countantsandAuditorsforSMEs_0_151125_EFAA_Response_IASB_Conceptual_Framework. pdf

Rivera, A. R. L., Arbelo, H. J. R., Ruiz, A. D. A., Rodríguez, J., Vega, L., García, W. C., Clemente, K. A. B., . . Fardonk, J. (2014). IASB and FASB convergence project: Where are they now? Paper presented at the, 9(1) 665-674. Retrieved from http://www.theibfr.com/ARCHIVE/ISSN-1941-9589-V9-N1-2014.pdf

Saeglitz, H. J. (2015). Comment letter to ED/2015/3. Retrieved from http://eifrs.ifrs.org/eifrs/comment_letters/50/50_5701_HansJuergenSaeglitzGermanInsurance AssociationGDV_0_GDV_CL_IASB_Conceptual_Framework_ED_151118.pdf

Schneider, B. (2015). Comment letter to ED/2015/3. Retrieved from http://eifrs.ifrs.org/eifrs/comment_letters/50/50_5313_BjoernSchneiderTheLindeGroup_0_T heLindeGroup.pdf

Shang, T. (2015). The latest progress of the conceptual framework. Modern Economy, 6(6), 
694-699. Retrieved from http://dx.doi.org/10.4236/me.2015.66065

Stachniak, A. (2015). Comment letter to ED/2015/3. Retrieved from http://eifrs.ifrs.org/eifrs/comment_letters/50/50_5841_AgnieszkaStachniakPolishAccounting StandardsCommittee_0_ConceptualFrameworkPASCcommentletter.doc

Stylianou, V. (2015). Comment letter to ED/2015/3. Retrieved from http://eifrs.ifrs.org/eifrs/comment_letters/50/50_5959_VickiStylianouTheInstituteofPublicAc countantsIPAAustralia_0_SubIASBAASBFramework30112015.pdf

Takahashi, S. (2015). Comment letter to ED/2015/3. Retrieved from http://eifrs.ifrs.org/eifrs/comment_letters/50/50_5781_SilvioTakahashiCPCBrazil_0_EDConc eptualFramework.pdf

Tysiac, K. (2012, December 19). Conceptual framework among IASB priorities. Journal of Accountancy.

Retrieved

from

http://www.journalofaccountancy.com/news/2012/dec/20127038.html

Uwe Fulbier, R., \& Klein, M. (2014). Balancing past and present: Impact of accounting internationalization on German accounting regulation. Retrieved from http://dx.doi.org/10.2139/ssrn.2200805

Wagenhofer, A. (2015). The never ending story of prudence and IFRS. IFAC Business Reporting. Retrieved from https://www.ifac.org/global-knowledge-gateway/business-reporting/discussion/never-endingstory-prudence-and-ifrs

Wesolowski, T. (2015). Comment letter to ED/2015/3. Retrieved from http://eifrs.ifrs.org/eifrs/comment_letters/50/50_5815_TomaszWesolowskiPrivate_0_Comme ntontheExposureDraftED_2015_3ConceptualFrameworkforFinancialReporting.pdf

Whitfield, A. T. (2015). Comment letter to ED/2015/3. Retrieved from http://eifrs.ifrs.org/eifrs/comment_letters/50/50_5294_ATWhitfieldAustralasianCouncilofAu ditorsGeneralACAG_0_AustralasianCouncilofAuditorsGeneralACAG.pdf

Wijesingha, U. (2015). Comment letter to ED/2015/3. Retrieved from http://eifrs.ifrs.org/eifrs/comment_letters/50/50_5700_UpendraWijesinghaTheInstituteofChar teredAccountantsofSriLanka_1_CommentsonED_2015_3_CASriLanka.pdf

Williams, K. (2015). Comment letter to ED/2015/3. Retrieved from http://eifrs.ifrs.org/eifrs/comment_letters/50/50_5791_KevinWilliamsThe100Group_0_100Gr oupConceptualFrameworkforFinancialReporting.pdf

Yoo, S. K. (2015). Comment letter to ED/2015/3. Retrieved from http://eifrs.ifrs.org/eifrs/comment_letters/50/50_5720_SEUNGKYOUNGYOOTHEKOREA NINSTITUTEOFCERTIFIEDPUBLICACCOUNTANTS_0_KICPACommentLetter_ED_Co nceptualFrameworkforFinancialReporting.pdf

Zeff, S. A. (2003). How the U.S. accounting profession got where it is today: Part I. 
189-205.

Retrieved

from http://www.ruf.rice.edu/ sazeff/PDF/Horizons, \%20Part\%20I\%20(print).pdf

Table 3. Analysis of Comment Letters - Questions 1, 2, 3, \& 4

\begin{tabular}{|c|c|c|c|c|c|c|c|c|c|c|c|c|c|}
\hline \multirow{2}{*}{ C.L. \# } & \multicolumn{13}{|c|}{ Question Number } \\
\hline & $1 \mathbf{a}$ & $1 \mathbf{b}$ & 1c & 1d & $1 e$ & $2 \mathbf{a}$ & $2 \mathbf{b}$ & $3 \mathbf{a}$ & $3 \mathbf{b}$ & $3 c$ & 3d & $3 e$ & 4 \\
\hline 4 & A & A & A & A & A & A & $\mathrm{D}$ & $\mathrm{D}$ & $\mathrm{D}$ & $\mathrm{N}$ & $\mathrm{N}$ & $\mathrm{N}$ & $\mathrm{D}$ \\
\hline 8 & $\mathrm{~A}$ & $\mathrm{~A}$ & A & A & A & A & A & A & A & A & A & A & A \\
\hline 13 & A & A & A & $\mathrm{D}$ & A & A & A & A & A & A & A & A & A \\
\hline 14 & A & A & A & $\mathrm{D}$ & $\mathrm{D}$ & A & $\mathrm{D}$ & A & $\mathrm{D}$ & A & $\mathrm{D}$ & $\mathrm{D}$ & A \\
\hline 15 & A & $\mathrm{D}$ & A & D & A & A & A & A & D & A & $\mathrm{N}$ & $\mathrm{N}$ & A \\
\hline 16 & A & A & A & A & A & A & A & A & A & A & A & A & A \\
\hline 18 & A & A & A & A & $\mathrm{D}$ & $\mathrm{N}$ & $\mathrm{N}$ & A & A & A & $\mathrm{A}$ & A & A \\
\hline 20 & A & D & A & A & A & A & $\mathrm{D}$ & A & A & A & A & A & A \\
\hline 24 & $\mathrm{D}$ & $\mathrm{D}$ & A & D & D & A & D & A & A & A & $\mathrm{D}$ & $\mathrm{D}$ & A \\
\hline 29 & A & D & A & A & A & $\mathrm{N}$ & D & $\mathrm{D}$ & $\mathrm{D}$ & A & A & A & A \\
\hline 33 & A & D & A & D & D & A & A & A & A & A & A & A & A \\
\hline 35 & A & A & A & A & A & A & A & A & A & A & A & A & A \\
\hline 36 & A & A & A & D & D & A & $\mathrm{D}$ & D & $\mathrm{D}$ & D & D & $\mathrm{D}$ & A \\
\hline 38 & A & A & A & A & A & A & A & $\mathrm{N}$ & $\mathrm{N}$ & $\mathrm{N}$ & $\mathrm{N}$ & $\mathrm{N}$ & A \\
\hline 42 & A & D & A & A & A & $\mathrm{D}$ & $\mathrm{D}$ & A & A & A & A & A & A \\
\hline 51 & A & D & A & A & A & D & $\mathrm{D}$ & A & A & A & D & $\mathrm{D}$ & A \\
\hline 52 & A & A & A & A & A & A & D & A & A & A & A & A & A \\
\hline 56 & A & D & A & A & A & A & D & A & A & A & A & A & A \\
\hline 61 & A & A & A & A & A & A & $\mathrm{D}$ & A & A & A & A & A & A \\
\hline 63 & A & A & D & D & D & A & A & A & $\mathrm{N}$ & $\mathrm{N}$ & A & A & A \\
\hline 64 & A & A & A & A & A & A & A & D & A & A & A & A & A \\
\hline 78 & A & A & A & A & A & A & A & A & A & A & A & A & $\mathrm{D}$ \\
\hline 80 & $\mathrm{D}$ & $\mathrm{D}$ & A & A & A & $\mathrm{A}$ & $\mathrm{D}$ & A & $\mathrm{D}$ & D & D & $\mathrm{D}$ & A \\
\hline 83 & A & D & A & D & A & $\mathrm{N}$ & $\mathrm{D}$ & $\mathrm{N}$ & $\mathrm{D}$ & A & $\mathrm{N}$ & $\mathrm{N}$ & D \\
\hline 84 & A & D & A & A & A & $\mathrm{N}$ & $\mathrm{N}$ & A & A & A & A & A & A \\
\hline 85 & A & A & A & A & A & A & A & A & A & A & A & A & A \\
\hline 96 & A & D & A & A & A & A & A & A & $\mathrm{D}$ & D & $\mathrm{N}$ & $\mathrm{N}$ & D \\
\hline 98 & $\mathrm{~A}$ & $\mathrm{D}$ & A & A & $\mathrm{D}$ & $\mathrm{N}$ & $\mathrm{D}$ & A & $\mathrm{D}$ & A & A & A & D \\
\hline 99 & A & D & A & A & A & A & A & A & A & A & A & A & $\mathrm{D}$ \\
\hline 102 & A & A & A & A & A & A & A & A & A & A & A & A & A \\
\hline 105 & A & A & A & A & A & A & D & D & D & D & $\mathrm{N}$ & $\mathrm{N}$ & D \\
\hline 106 & D & D & A & D & A & D & $\mathrm{D}$ & A & A & A & A & A & D \\
\hline
\end{tabular}




\begin{tabular}{|c|c|c|c|c|c|c|c|c|c|c|c|c|c|}
\hline $\mathbf{1 0 8}$ & A & A & A & A & D & A & A & D & A & A & D & D & A \\
\hline $\mathbf{1 1 4}$ & A & A & A & A & A & A & A & N & A & D & D & D & D \\
\hline $\mathbf{1 1 8}$ & A & D & A & D & D & A & D & A & A & A & D & D & A \\
\hline $\mathbf{1 2 6}$ & A & D & A & A & A & A & D & A & A & A & A & A & A \\
\hline $\mathbf{1 3 0}$ & A & A & A & A & A & D & D & A & D & A & A & A & A \\
\hline $\mathbf{1 3 2}$ & A & D & A & A & A & D & D & A & A & A & A & A & D \\
\hline $\mathbf{1 4 8}$ & A & A & A & A & A & D & D & A & A & A & A & A & A \\
\hline $\mathbf{1 4 9}$ & A & A & A & A & A & A & A & A & A & A & A & A & A \\
\hline
\end{tabular}

Note. $\mathrm{A}=$ Agree, $\mathrm{D}=$ Disagree, $\mathrm{N}=$ No Comment.

Table 3. Continued

\begin{tabular}{|c|c|c|c|c|c|c|c|c|c|c|c|c|c|}
\hline \multirow{2}{*}{ C.L. \# } & \multicolumn{13}{|c|}{ Question Number } \\
\hline & $\mathbf{1 a}$ & $1 \mathbf{b}$ & 1c & 1d & $1 e$ & $2 \mathbf{a}$ & $2 \mathbf{b}$ & $3 \mathbf{a}$ & $3 \mathbf{b}$ & $3 c$ & $3 d$ & $3 e$ & 4 \\
\hline 165 & $\mathrm{~A}$ & $\mathrm{D}$ & $\mathrm{A}$ & $\mathrm{A}$ & $\mathrm{N}$ & $\mathrm{A}$ & $\mathrm{A}$ & $\mathrm{A}$ & $\mathrm{A}$ & $\mathrm{D}$ & $\mathrm{A}$ & $\mathrm{A}$ & $\mathrm{A}$ \\
\hline 167 & $\mathrm{~A}$ & A & $\mathrm{A}$ & A & $\mathrm{A}$ & A & $\mathrm{D}$ & $\mathrm{A}$ & A & $\mathrm{A}$ & $\mathrm{A}$ & $\mathrm{A}$ & A \\
\hline 172 & A & A & A & A & A & A & $\mathrm{D}$ & A & A & A & A & A & A \\
\hline 174 & A & $\mathrm{D}$ & A & A & A & A & A & $\mathrm{D}$ & $\mathrm{D}$ & $\mathrm{D}$ & $\mathrm{N}$ & $\mathrm{N}$ & A \\
\hline 177 & $\mathrm{~A}$ & A & A & $\mathrm{D}$ & A & A & A & $\mathrm{D}$ & $\mathrm{D}$ & A & A & A & $\mathrm{D}$ \\
\hline 178 & $\mathrm{~A}$ & $\mathrm{~A}$ & $\mathrm{~A}$ & $\mathrm{D}$ & $\mathrm{A}$ & $\mathrm{A}$ & $\mathrm{A}$ & A & $\mathrm{D}$ & $\mathrm{A}$ & $\mathrm{A}$ & $\mathrm{A}$ & $\mathrm{D}$ \\
\hline 179 & $\mathrm{D}$ & $A$ & $A$ & $A$ & $\mathrm{D}$ & $\mathrm{D}$ & $\mathrm{D}$ & $\mathrm{N}$ & $\mathrm{D}$ & $\mathrm{D}$ & $\mathrm{N}$ & $\mathrm{N}$ & $\mathrm{D}$ \\
\hline 180 & A & $\mathrm{A}$ & A & $\mathrm{A}$ & A & $\mathrm{A}$ & $\mathrm{A}$ & A & $A$ & A & $\mathrm{D}$ & $\mathrm{D}$ & $\mathrm{D}$ \\
\hline 182 & $\mathrm{~A}$ & $\mathrm{~A}$ & $\mathrm{~A}$ & $\mathrm{~A}$ & $\mathrm{~A}$ & $\mathrm{~A}$ & $\mathrm{~A}$ & $\mathrm{~A}$ & $\mathrm{~A}$ & $\mathrm{~N}$ & $\mathrm{~N}$ & $\mathrm{~N}$ & $\mathrm{~A}$ \\
\hline 183 & $\mathrm{~A}$ & $\mathrm{~A}$ & $\mathrm{~A}$ & $\mathrm{~A}$ & $\mathrm{~A}$ & $\mathrm{~A}$ & $\mathrm{~A}$ & $\mathrm{~A}$ & $\mathrm{~A}$ & $\mathrm{~N}$ & $\mathrm{~N}$ & $\mathrm{~N}$ & $\mathrm{~A}$ \\
\hline 188 & $\mathrm{D}$ & $\mathrm{A}$ & $\mathrm{N}$ & $\mathrm{A}$ & $\mathrm{A}$ & $\mathrm{A}$ & $\mathrm{D}$ & $\mathrm{A}$ & $\mathrm{A}$ & $\mathrm{N}$ & $\mathrm{N}$ & $\mathrm{N}$ & D \\
\hline 189 & $\mathrm{~A}$ & $\mathrm{~A}$ & $\mathrm{~A}$ & $\mathrm{D}$ & $\mathrm{A}$ & $\mathrm{A}$ & $\mathrm{D}$ & $\mathrm{A}$ & $\mathrm{A}$ & $\mathrm{D}$ & $\mathrm{D}$ & $\mathrm{D}$ & $\mathrm{A}$ \\
\hline 192 & $\mathrm{~A}$ & $\mathrm{D}$ & $\mathrm{A}$ & $\mathrm{A}$ & $\mathrm{A}$ & $\mathrm{A}$ & $\mathrm{D}$ & $\mathrm{A}$ & $\mathrm{A}$ & $\mathrm{A}$ & $\mathrm{A}$ & $\mathrm{A}$ & $\mathrm{D}$ \\
\hline 197 & A & A & A & A & A & $\mathrm{N}$ & $\mathrm{D}$ & $\mathrm{D}$ & $\mathrm{D}$ & $\mathrm{N}$ & A & A & A \\
\hline 199 & $\mathrm{~A}$ & $\mathrm{D}$ & $\mathrm{A}$ & $\mathrm{A}$ & A & A & $\mathrm{D}$ & $\mathrm{A}$ & A & A & $\mathrm{A}$ & $\mathrm{A}$ & A \\
\hline 200 & $\mathrm{D}$ & $\mathrm{A}$ & A & A & $\mathrm{A}$ & $\mathrm{D}$ & $\mathrm{D}$ & A & $\mathrm{A}$ & $\mathrm{D}$ & $\mathrm{D}$ & $\mathrm{D}$ & A \\
\hline 201 & A & $\mathrm{A}$ & $\mathrm{N}$ & $\mathrm{N}$ & $\mathrm{A}$ & $\mathrm{N}$ & $\mathrm{N}$ & $\mathrm{N}$ & $\mathrm{D}$ & $\mathrm{N}$ & $\mathrm{N}$ & $\mathrm{N}$ & $\mathrm{D}$ \\
\hline 203 & $\mathrm{~A}$ & $\mathrm{~A}$ & $\mathrm{D}$ & $\mathrm{A}$ & $\mathrm{A}$ & $\mathrm{A}$ & $\mathrm{A}$ & $\mathrm{A}$ & $\mathrm{A}$ & $\mathrm{A}$ & $\mathrm{A}$ & $\mathrm{A}$ & $\mathrm{D}$ \\
\hline 204 & $\mathrm{~A}$ & $\mathrm{D}$ & $\mathrm{A}$ & $\mathrm{D}$ & $\mathrm{A}$ & $\mathrm{A}$ & $\mathrm{A}$ & A & $\mathrm{A}$ & $\mathrm{A}$ & $\mathrm{A}$ & $\mathrm{A}$ & A \\
\hline 205 & $\mathrm{~A}$ & $\mathrm{~A}$ & $\mathrm{~A}$ & $\mathrm{D}$ & $\mathrm{A}$ & $\mathrm{A}$ & $\mathrm{A}$ & $\mathrm{D}$ & $\mathrm{A}$ & $\mathrm{A}$ & $\mathrm{D}$ & $\mathrm{D}$ & $\mathrm{A}$ \\
\hline 207 & A & A & A & $\mathrm{D}$ & A & A & $\mathrm{D}$ & A & A & $\mathrm{D}$ & A & A & A \\
\hline 208 & A & A & A & $\mathrm{D}$ & A & A & $\mathrm{D}$ & A & A & $\mathrm{D}$ & $\mathrm{D}$ & $\mathrm{D}$ & A \\
\hline 209 & $\mathrm{~A}$ & A & $\mathrm{N}$ & $\mathrm{N}$ & $\mathrm{N}$ & $\mathrm{D}$ & $\mathrm{D}$ & $\mathrm{A}$ & A & A & A & A & $\mathrm{D}$ \\
\hline 210 & $\mathrm{~A}$ & A & A & A & $\mathrm{D}$ & A & $\mathrm{D}$ & $\mathrm{A}$ & A & A & A & A & A \\
\hline 211 & $\mathrm{~A}$ & $\mathrm{~A}$ & A & A & $\mathrm{A}$ & $\mathrm{A}$ & $\mathrm{A}$ & A & $\mathrm{D}$ & $\mathrm{A}$ & $\mathrm{D}$ & $\mathrm{A}$ & $\mathrm{A}$ \\
\hline
\end{tabular}




\begin{tabular}{|c|c|c|c|c|c|c|c|c|c|c|c|c|c|}
\hline $\mathbf{2 1 2}$ & D & A & A & A & A & A & A & A & A & D & A & A & N \\
\hline 213 & A & A & A & A & A & A & A & D & D & D & N & N & D \\
\hline 214 & A & A & A & A & A & A & D & D & D & D & D & D & A \\
\hline 215 & A & A & N & N & A & A & D & A & A & A & A & A & D \\
\hline 216 & A & A & A & D & N & A & A & D & A & A & A & A & D \\
\hline $\mathbf{2 1 7}$ & A & A & A & A & A & A & D & A & D & D & A & A & A \\
\hline \# A & $\mathbf{6 5}$ & 49 & $\mathbf{6 6}$ & $\mathbf{5 1}$ & $\mathbf{5 8}$ & $\mathbf{5 6}$ & $\mathbf{3 1}$ & $\mathbf{5 4}$ & $\mathbf{4 9}$ & $\mathbf{4 8}$ & $\mathbf{4 4}$ & $\mathbf{4 5}$ & $\mathbf{4 8}$ \\
\hline \# D & $\mathbf{7}$ & $\mathbf{2 3}$ & $\mathbf{2}$ & $\mathbf{1 8}$ & $\mathbf{1 1}$ & $\mathbf{9}$ & $\mathbf{3 8}$ & $\mathbf{1 3}$ & $\mathbf{2 1}$ & $\mathbf{1 6}$ & $\mathbf{1 5}$ & $\mathbf{1 4}$ & $\mathbf{2 3}$ \\
\hline \# N & $\mathbf{0}$ & $\mathbf{0}$ & $\mathbf{4}$ & $\mathbf{3}$ & $\mathbf{3}$ & $\mathbf{7}$ & $\mathbf{3}$ & $\mathbf{5}$ & $\mathbf{2}$ & $\mathbf{8}$ & $\mathbf{1 3}$ & $\mathbf{1 3}$ & $\mathbf{1}$ \\
\hline $\boldsymbol{\%}$ A & $\mathbf{9 0 \%}$ & $\mathbf{6 8 \%}$ & $\mathbf{9 2 \%}$ & $\mathbf{7 1 \%}$ & $\mathbf{8 1 \%}$ & $\mathbf{7 8 \%}$ & $\mathbf{4 3 \%}$ & $\mathbf{7 5 \%}$ & $\mathbf{6 8 \%}$ & $\mathbf{6 7 \%}$ & $\mathbf{6 1 \%}$ & $\mathbf{6 3 \%}$ & $\mathbf{6 7 \%}$ \\
\hline $\boldsymbol{\%} \mathrm{D}$ & $\mathbf{1 0 \%}$ & $\mathbf{3 2 \%}$ & $\mathbf{3 \%}$ & $\mathbf{2 5 \%}$ & $\mathbf{1 5 \%}$ & $\mathbf{1 3 \%}$ & $\mathbf{5 3 \%}$ & $\mathbf{1 8 \%}$ & $\mathbf{2 9 \%}$ & $\mathbf{2 2 \%}$ & $\mathbf{2 1 \%}$ & $\mathbf{1 9 \%}$ & $\mathbf{3 2 \%}$ \\
\hline$\%$ N & $\mathbf{0 \%}$ & $\mathbf{0 \%}$ & $\mathbf{5 \%}$ & $\mathbf{4 \%}$ & $\mathbf{4 \%}$ & $\mathbf{9 \%}$ & $\mathbf{4 \%}$ & $\mathbf{7 \%}$ & $\mathbf{3 \%}$ & $\mathbf{1 1 \%}$ & $\mathbf{1 8 \%}$ & $\mathbf{1 8 \%}$ & $\mathbf{1 \%}$ \\
\hline
\end{tabular}

Note. $\mathrm{A}=$ Agree, $\mathrm{D}=$ Disagree, $\mathrm{N}=\mathrm{No}$ Comment.

Table 4. Analysis of Comment Letters - Questions 6, 7, 8, 9, 10, 12, 13, 14, 15, 16, \& 17

\begin{tabular}{|c|c|c|c|c|c|c|c|c|c|c|c|c|}
\hline \multirow{2}{*}{ C.L. \# } & \multicolumn{12}{|c|}{ Question Number } \\
\hline & 6 & 7 & $8 a$ & $8 b$ & 9 & 10 & 12 & 13 & 14 & 15 & 16 & 17 \\
\hline 4 & A & A & A & A & A & A & $\mathrm{D}$ & $\mathrm{D}$ & $\mathrm{D}$ & A & $\mathrm{A}$ & A \\
\hline 8 & A & A & A & A & A & A & A & A & $\mathrm{D}$ & A & $\mathrm{D}$ & A \\
\hline 13 & A & $\mathrm{A}$ & A & A & A & A & $\mathrm{A}$ & A & $\mathrm{D}$ & A & A & $\mathrm{A}$ \\
\hline 14 & A & A & $\mathrm{D}$ & $\mathrm{D}$ & $\mathrm{N}$ & $\mathrm{D}$ & A & $\mathrm{D}$ & $\mathrm{D}$ & $\mathrm{D}$ & $\mathrm{A}$ & $\mathrm{A}$ \\
\hline 15 & A & $\mathrm{A}$ & $\mathrm{A}$ & A & A & A & A & $\mathrm{D}$ & A & $\mathrm{D}$ & A & $\mathrm{A}$ \\
\hline 16 & $\mathrm{~A}$ & $\mathrm{~A}$ & $\mathrm{~A}$ & $\mathrm{~A}$ & A & A & $\mathrm{A}$ & $\mathrm{D}$ & $\mathrm{D}$ & A & A & $\mathrm{A}$ \\
\hline 18 & $\mathrm{~N}$ & $\mathrm{~N}$ & A & A & A & A & A & $\mathrm{D}$ & A & $\mathrm{D}$ & $\mathrm{D}$ & A \\
\hline 20 & A & A & $\mathrm{D}$ & $\mathrm{D}$ & A & $\mathrm{D}$ & $\mathrm{D}$ & $\mathrm{D}$ & $\mathrm{D}$ & A & A & A \\
\hline 24 & $\mathrm{~A}$ & $\mathrm{~A}$ & A & A & D & A & $\mathrm{D}$ & $\mathrm{D}$ & $\mathrm{D}$ & $\mathrm{N}$ & A & $\mathrm{A}$ \\
\hline 29 & A & A & A & A & A & A & $\mathrm{D}$ & $\mathrm{D}$ & $\mathrm{D}$ & $\mathrm{N}$ & $\mathrm{D}$ & A \\
\hline 33 & A & A & A & A & A & A & A & $\mathrm{D}$ & $\mathrm{D}$ & A & A & A \\
\hline 35 & A & A & A & A & D & A & $\mathrm{D}$ & $\mathrm{D}$ & D & D & A & A \\
\hline 36 & A & A & A & A & D & $\mathrm{D}$ & $\mathrm{D}$ & $\mathrm{D}$ & $\mathrm{D}$ & A & A & $\mathrm{D}$ \\
\hline 38 & D & A & A & A & A & A & D & $\mathrm{N}$ & $\mathrm{N}$ & $\mathrm{N}$ & D & A \\
\hline 42 & A & A & A & A & A & A & $\mathrm{D}$ & $\mathrm{D}$ & $\mathrm{D}$ & A & $\mathrm{D}$ & A \\
\hline 51 & A & A & A & A & A & A & D & D & D & $\mathrm{N}$ & D & A \\
\hline 52 & A & A & A & A & A & A & A & D & D & A & A & A \\
\hline 56 & $\mathrm{~A}$ & $\mathrm{~A}$ & $\mathrm{~A}$ & $\mathrm{~A}$ & A & $\mathrm{A}$ & $\mathrm{D}$ & $\mathrm{D}$ & $\mathrm{D}$ & $\mathrm{D}$ & $\mathrm{A}$ & $\mathrm{A}$ \\
\hline 61 & $\mathrm{~A}$ & $\mathrm{~A}$ & $\mathrm{D}$ & $\mathrm{D}$ & A & $\mathrm{A}$ & $\mathrm{D}$ & $\mathrm{D}$ & $\mathrm{D}$ & $\mathrm{A}$ & $\mathrm{D}$ & $\mathrm{A}$ \\
\hline 63 & $\mathrm{~A}$ & $\mathrm{~A}$ & $\mathrm{D}$ & $\mathrm{D}$ & $\mathrm{D}$ & $\mathrm{A}$ & $\mathrm{A}$ & $\mathrm{A}$ & $\mathrm{A}$ & $\mathrm{A}$ & $\mathrm{D}$ & $\mathrm{D}$ \\
\hline 64 & $\mathrm{D}$ & $\mathrm{A}$ & A & $\mathrm{A}$ & A & $\mathrm{A}$ & $\mathrm{D}$ & $\mathrm{D}$ & $\mathrm{D}$ & $\mathrm{A}$ & $\mathrm{D}$ & $\mathrm{A}$ \\
\hline 78 & $\mathrm{D}$ & $\mathrm{D}$ & D & A & A & A & $\mathrm{D}$ & $\mathrm{D}$ & $\mathrm{D}$ & A & A & $\mathrm{A}$ \\
\hline
\end{tabular}




\begin{tabular}{|c|c|c|c|c|c|c|c|c|c|c|c|c|}
\hline $\mathbf{8 0}$ & $\mathrm{D}$ & $\mathrm{A}$ & $\mathrm{D}$ & $\mathrm{D}$ & $\mathrm{D}$ & $\mathrm{D}$ & $\mathrm{D}$ & $\mathrm{D}$ & $\mathrm{D}$ & $\mathrm{D}$ & $\mathrm{A}$ & $\mathrm{A}$ \\
\hline $\mathbf{8 3}$ & $\mathrm{N}$ & $\mathrm{N}$ & $\mathrm{A}$ & $\mathrm{A}$ & $\mathrm{A}$ & $\mathrm{A}$ & $\mathrm{D}$ & $\mathrm{D}$ & $\mathrm{D}$ & $\mathrm{A}$ & $\mathrm{A}$ & $\mathrm{N}$ \\
\hline $\mathbf{8 4}$ & $\mathrm{A}$ & $\mathrm{A}$ & $\mathrm{N}$ & $\mathrm{N}$ & $\mathrm{N}$ & $\mathrm{N}$ & $\mathrm{A}$ & $\mathrm{D}$ & $\mathrm{D}$ & $\mathrm{N}$ & $\mathrm{A}$ & $\mathrm{A}$ \\
\hline $\mathbf{8 5}$ & $\mathrm{A}$ & $\mathrm{A}$ & $\mathrm{A}$ & $\mathrm{A}$ & $\mathrm{A}$ & $\mathrm{A}$ & $\mathrm{A}$ & $\mathrm{A}$ & $\mathrm{A}$ & $\mathrm{A}$ & $\mathrm{A}$ & $\mathrm{A}$ \\
\hline $\mathbf{9 6}$ & $\mathrm{A}$ & $\mathrm{A}$ & $\mathrm{A}$ & $\mathrm{D}$ & $\mathrm{A}$ & $\mathrm{D}$ & $\mathrm{A}$ & $\mathrm{D}$ & $\mathrm{D}$ & $\mathrm{N}$ & $\mathrm{A}$ & $\mathrm{A}$ \\
\hline $\mathbf{9 8}$ & $\mathrm{N}$ & $\mathrm{N}$ & $\mathrm{D}$ & $\mathrm{D}$ & $\mathrm{D}$ & $\mathrm{D}$ & $\mathrm{D}$ & $\mathrm{D}$ & $\mathrm{D}$ & $\mathrm{D}$ & $\mathrm{D}$ & $\mathrm{N}$ \\
\hline $\mathbf{9 9}$ & $\mathrm{D}$ & $\mathrm{A}$ & $\mathrm{A}$ & $\mathrm{A}$ & $\mathrm{A}$ & $\mathrm{A}$ & $\mathrm{D}$ & $\mathrm{D}$ & $\mathrm{A}$ & $\mathrm{A}$ & $\mathrm{A}$ & $\mathrm{D}$ \\
\hline $\mathbf{1 0 2}$ & $\mathrm{A}$ & $\mathrm{A}$ & $\mathrm{N}$ & $\mathrm{N}$ & $\mathrm{D}$ & $\mathrm{A}$ & $\mathrm{D}$ & $\mathrm{D}$ & $\mathrm{A}$ & $\mathrm{A}$ & $\mathrm{A}$ & $\mathrm{A}$ \\
\hline $\mathbf{1 0 5}$ & $\mathrm{A}$ & $\mathrm{A}$ & $\mathrm{A}$ & $\mathrm{A}$ & $\mathrm{D}$ & $\mathrm{D}$ & $\mathrm{A}$ & $\mathrm{D}$ & $\mathrm{A}$ & $\mathrm{A}$ & $\mathrm{D}$ & $\mathrm{A}$ \\
\hline $\mathbf{1 0 6}$ & $\mathrm{D}$ & $\mathrm{A}$ & $\mathrm{A}$ & $\mathrm{A}$ & $\mathrm{D}$ & $\mathrm{A}$ & $\mathrm{A}$ & $\mathrm{D}$ & $\mathrm{D}$ & $\mathrm{A}$ & $\mathrm{A}$ & $\mathrm{A}$ \\
\hline $\mathbf{1 0 8}$ & $\mathrm{D}$ & $\mathrm{A}$ & $\mathrm{A}$ & $\mathrm{A}$ & $\mathrm{D}$ & $\mathrm{A}$ & $\mathrm{D}$ & $\mathrm{D}$ & $\mathrm{D}$ & $\mathrm{D}$ & $\mathrm{D}$ & $\mathrm{A}$ \\
\hline $\mathbf{1 1 4}$ & $\mathrm{A}$ & $\mathrm{A}$ & $\mathrm{D}$ & $\mathrm{D}$ & $\mathrm{A}$ & $\mathrm{A}$ & $\mathrm{A}$ & $\mathrm{D}$ & $\mathrm{D}$ & $\mathrm{A}$ & $\mathrm{A}$ & $\mathrm{D}$ \\
\hline $\mathbf{1 1 8}$ & $\mathrm{A}$ & $\mathrm{A}$ & $\mathrm{D}$ & $\mathrm{D}$ & $\mathrm{D}$ & $\mathrm{A}$ & $\mathrm{D}$ & $\mathrm{D}$ & $\mathrm{A}$ & $\mathrm{A}$ & $\mathrm{A}$ & $\mathrm{A}$ \\
\hline $\mathbf{1 2 6}$ & $\mathrm{A}$ & $\mathrm{A}$ & $\mathrm{A}$ & $\mathrm{A}$ & $\mathrm{A}$ & $\mathrm{D}$ & $\mathrm{A}$ & $\mathrm{D}$ & $\mathrm{D}$ & $\mathrm{A}$ & $\mathrm{A}$ & $\mathrm{A}$ \\
\hline $\mathbf{1 3 0}$ & $\mathrm{D}$ & $\mathrm{A}$ & $\mathrm{D}$ & $\mathrm{D}$ & $\mathrm{A}$ & $\mathrm{A}$ & $\mathrm{D}$ & $\mathrm{A}$ & $\mathrm{D}$ & $\mathrm{A}$ & $\mathrm{N}$ & $\mathrm{N}$ \\
\hline $\mathbf{1 3 2}$ & $\mathrm{A}$ & $\mathrm{A}$ & $\mathrm{A}$ & $\mathrm{A}$ & $\mathrm{A}$ & $\mathrm{D}$ & $\mathrm{A}$ & $\mathrm{D}$ & $\mathrm{D}$ & $\mathrm{A}$ & $\mathrm{A}$ & $\mathrm{A}$ \\
\hline $\mathbf{1 4 8}$ & $\mathrm{A}$ & $\mathrm{A}$ & $\mathrm{A}$ & $\mathrm{A}$ & $\mathrm{A}$ & $\mathrm{A}$ & $\mathrm{A}$ & $\mathrm{A}$ & $\mathrm{A}$ & $\mathrm{D}$ & $\mathrm{A}$ & $\mathrm{A}$ \\
\hline $\mathbf{1 4 9}$ & $\mathrm{A}$ & $\mathrm{D}$ & $\mathrm{A}$ & $\mathrm{A}$ & $\mathrm{A}$ & $\mathrm{D}$ & $\mathrm{A}$ & $\mathrm{A}$ & $\mathrm{A}$ & $\mathrm{A}$ & $\mathrm{A}$ & $\mathrm{A}$ \\
\hline $\mathbf{1 5 7}$ & $\mathrm{A}$ & $\mathrm{D}$ & $\mathrm{D}$ & $\mathrm{D}$ & $\mathrm{D}$ & $\mathrm{D}$ & $\mathrm{D}$ & $\mathrm{D}$ & $\mathrm{A}$ & $\mathrm{A}$ & $\mathrm{D}$ & $\mathrm{A}$ \\
\hline
\end{tabular}

Note. $\mathrm{A}=$ Agree, $\mathrm{D}=$ Disagree, $\mathrm{N}=$ No Comment.

Table 4. Continued

\begin{tabular}{|c|c|c|c|c|c|c|c|c|c|c|c|c|}
\hline \multirow{2}{*}{ C.L. \# } & \multicolumn{10}{c|}{ Question Number } \\
\cline { 2 - 15 } & $\mathbf{6}$ & $\mathbf{7}$ & $\mathbf{8 a}$ & $\mathbf{8 b}$ & $\mathbf{9}$ & $\mathbf{1 0}$ & $\mathbf{1 2}$ & $\mathbf{1 3}$ & $\mathbf{1 4}$ & $\mathbf{1 5}$ & $\mathbf{1 6}$ & $\mathbf{1 7}$ \\
\hline $\mathbf{1 6 5}$ & A & A & A & A & D & A & D & D & D & A & A & A \\
\hline $\mathbf{1 6 7}$ & A & A & A & A & D & A & A & D & D & A & D & A \\
\hline $\mathbf{1 7 2}$ & A & A & A & A & A & A & A & D & A & D & A & D \\
\hline $\mathbf{1 7 4}$ & A & A & A & A & D & A & A & A & A & N & A & A \\
\hline $\mathbf{1 7 7}$ & A & A & A & A & A & A & A & D & D & D & A & A \\
\hline $\mathbf{1 7 8}$ & A & A & A & A & A & A & A & A & A & D & D & A \\
\hline $\mathbf{1 7 9}$ & D & D & A & A & D & D & D & D & A & N & A & D \\
\hline $\mathbf{1 8 0}$ & A & A & D & D & A & A & D & A & A & A & D & A \\
\hline $\mathbf{1 8 2}$ & A & A & A & A & A & A & A & D & D & D & A & A \\
\hline $\mathbf{1 8 3}$ & A & A & A & A & A & A & A & A & D & D & A & A \\
\hline $\mathbf{1 8 8}$ & D & A & A & A & A & A & A & A & A & D & A & A \\
\hline $\mathbf{1 8 9}$ & A & A & A & A & A & A & D & A & A & A & D & A \\
\hline $\mathbf{1 9 2}$ & D & A & A & A & A & D & A & D & D & N & D & A \\
\hline $\mathbf{1 9 7}$ & D & N & A & A & D & D & D & D & A & A & D & A \\
\hline $\mathbf{1 9 9}$ & A & A & D & D & A & D & A & D & D & A & A & A \\
\hline
\end{tabular}




\begin{tabular}{|c|c|c|c|c|c|c|c|c|c|c|c|c|}
\hline 200 & $\mathrm{D}$ & $\mathrm{D}$ & A & A & $\mathrm{D}$ & $\mathrm{D}$ & D & D & D & A & $\mathrm{D}$ & A \\
\hline 201 & $\mathrm{D}$ & $\mathrm{D}$ & A & A & $\mathrm{D}$ & $\mathrm{D}$ & $\mathrm{D}$ & $\mathrm{D}$ & $\mathrm{D}$ & $\mathrm{N}$ & $\mathrm{D}$ & $\mathrm{D}$ \\
\hline 203 & A & $\mathrm{D}$ & $\mathrm{D}$ & $\mathrm{D}$ & A & A & A & A & A & A & A & A \\
\hline 204 & A & $\mathrm{D}$ & A & A & $\mathrm{D}$ & A & $\mathrm{D}$ & $\mathrm{D}$ & $\mathrm{D}$ & $\mathrm{D}$ & A & A \\
\hline 205 & $\mathrm{D}$ & D & A & A & $\mathrm{D}$ & A & A & $\mathrm{D}$ & A & D & D & D \\
\hline 207 & A & A & A & A & $\mathrm{D}$ & A & A & $\mathrm{D}$ & D & A & D & A \\
\hline 208 & $\mathrm{D}$ & A & $\mathrm{D}$ & $\mathrm{D}$ & $\mathrm{D}$ & A & $\mathrm{D}$ & $\mathrm{D}$ & $\mathrm{D}$ & $\mathrm{D}$ & A & $\mathrm{D}$ \\
\hline 209 & A & A & A & A & A & A & $\mathrm{D}$ & $\mathrm{D}$ & $\mathrm{D}$ & A & A & $\mathrm{D}$ \\
\hline 210 & $\mathrm{D}$ & A & A & A & A & $\mathrm{D}$ & A & A & A & $\mathrm{D}$ & $\mathrm{D}$ & $\mathrm{D}$ \\
\hline 211 & A & A & A & A & A & A & A & A & A & A & A & A \\
\hline 212 & A & A & A & A & $\mathrm{D}$ & A & $\mathrm{D}$ & $\mathrm{D}$ & $\mathrm{D}$ & $\mathrm{N}$ & $\mathrm{D}$ & $\mathrm{N}$ \\
\hline 213 & $\mathrm{D}$ & A & A & A & A & A & A & A & $\mathrm{D}$ & A & A & A \\
\hline 214 & A & A & A & $\mathrm{N}$ & A & $\mathrm{D}$ & $\mathrm{D}$ & $\mathrm{D}$ & A & $\mathrm{D}$ & A & $\mathrm{D}$ \\
\hline 215 & $\mathrm{D}$ & A & A & $\mathrm{N}$ & $\mathrm{D}$ & A & $\mathrm{D}$ & $\mathrm{D}$ & $\mathrm{D}$ & A & $\mathrm{D}$ & A \\
\hline 216 & A & A & A & A & A & A & $\mathrm{D}$ & $\mathrm{D}$ & $\mathrm{D}$ & A & A & A \\
\hline 217 & A & $\mathrm{D}$ & A & A & A & A & $\mathrm{D}$ & $\mathrm{D}$ & $\mathrm{D}$ & $\mathrm{D}$ & $\mathrm{D}$ & A \\
\hline$\# \mathbf{A}$ & 50 & 58 & 55 & 53 & 45 & 52 & 35 & 17 & 24 & 40 & 44 & 56 \\
\hline \# D & 19 & 10 & 15 & 15 & 25 & 19 & 37 & 54 & 47 & 21 & 27 & 12 \\
\hline$\# \mathbf{N}$ & 3 & 4 & 2 & 4 & 2 & 1 & $\mathbf{0}$ & 1 & 1 & 11 & 1 & 4 \\
\hline$\% \mathrm{~A}$ & $69 \%$ & $81 \%$ & $76 \%$ & $74 \%$ & $63 \%$ & $72 \%$ & $49 \%$ & $24 \%$ & $34 \%$ & $56 \%$ & $61 \%$ & $78 \%$ \\
\hline$\% \mathrm{D}$ & $26 \%$ & $14 \%$ & $21 \%$ & $21 \%$ & $34 \%$ & $27 \%$ & $51 \%$ & $75 \%$ & $65 \%$ & $29 \%$ & $38 \%$ & $17 \%$ \\
\hline$\% \mathrm{~N}$ & $5 \%$ & $5 \%$ & $3 \%$ & $5 \%$ & $3 \%$ & $1 \%$ & $0 \%$ & $1 \%$ & $1 \%$ & $15 \%$ & $1 \%$ & $5 \%$ \\
\hline
\end{tabular}

Note. $\mathrm{A}=$ Agree, $\mathrm{D}=$ Disagree, $\mathrm{N}=$ No Comment.

Table 5. Analysis of Alternative Views ${ }^{a}$

\begin{tabular}{|c|c|c|c|c|c|}
\hline \multirow[b]{2}{*}{ C.L. \# } & \multicolumn{5}{|c|}{ Question Number } \\
\hline & $\begin{array}{l}\text { AV2-AV7 \& } \\
\text { AV29-AV33 }^{\text {b }}\end{array}$ & AV8-AV14 & $\mathbf{A V}^{\mathrm{d}}{ }^{\mathrm{d}}$ & $\begin{array}{l}\text { AV17-AV22 \& } \\
\text { AV27-AV28 }\end{array}$ & $\operatorname{AV} 23-A V 26^{f}$ \\
\hline 4 & $\mathrm{~A}$ & $\mathrm{D}$ & $\mathrm{D}$ & $\mathrm{D}$ & $\mathrm{D}$ \\
\hline 8 & A & $\mathrm{D}$ & $\mathrm{D}$ & $\mathrm{D}$ & $\mathrm{D}$ \\
\hline 13 & $\mathrm{D}$ & $\mathrm{D}$ & A & $\mathrm{D}$ & $\mathrm{D}$ \\
\hline 14 & A & $\mathrm{A}$ & $\mathrm{A}$ & $\mathrm{A}$ & $\mathrm{D}$ \\
\hline 15 & A & A & $\mathrm{D}$ & $\mathrm{D}$ & $\mathrm{D}$ \\
\hline 16 & A & $\mathrm{D}$ & A & $\mathrm{D}$ & $\mathrm{D}$ \\
\hline 18 & A & $\mathrm{D}$ & $\mathrm{D}$ & $\mathrm{D}$ & $\mathrm{D}$ \\
\hline 20 & A & A & A & A & $\mathrm{D}$ \\
\hline 24 & A & $\mathrm{D}$ & $\mathrm{A}$ & $\mathrm{D}$ & $\mathrm{A}$ \\
\hline 29 & A & $\mathrm{D}$ & A & $\mathrm{D}$ & $\mathrm{D}$ \\
\hline 33 & A & $\mathrm{D}$ & A & $\mathrm{D}$ & $\mathrm{D}$ \\
\hline
\end{tabular}




\section{1ll Macrothink}

\begin{tabular}{|c|c|c|c|c|c|}
\hline $\mathbf{3 5}$ & $\mathrm{A}$ & $\mathrm{D}$ & $\mathrm{D}$ & $\mathrm{D}$ & $\mathrm{D}$ \\
\hline $\mathbf{3 6}$ & $\mathrm{A}$ & $\mathrm{D}$ & $\mathrm{D}$ & $\mathrm{D}$ & $\mathrm{D}$ \\
\hline $\mathbf{3 8}$ & $\mathrm{A}$ & $\mathrm{D}$ & $\mathrm{A}$ & $\mathrm{D}$ & $\mathrm{D}$ \\
\hline $\mathbf{4 2}$ & $\mathrm{A}$ & $\mathrm{D}$ & $\mathrm{A}$ & $\mathrm{D}$ & $\mathrm{D}$ \\
\hline $\mathbf{5 1}$ & $\mathrm{A}$ & $\mathrm{D}$ & $\mathrm{A}$ & $\mathrm{A}$ & $\mathrm{D}$ \\
\hline $\mathbf{5 2}$ & $\mathrm{A}$ & $\mathrm{A}$ & $\mathrm{D}$ & $\mathrm{D}$ & $\mathrm{D}$ \\
\hline $\mathbf{5 6}$ & $\mathrm{A}$ & $\mathrm{D}$ & $\mathrm{A}$ & $\mathrm{D}$ & $\mathrm{D}$ \\
\hline $\mathbf{6 1}$ & $\mathrm{A}$ & $\mathrm{D}$ & $\mathrm{D}$ & $\mathrm{D}$ & $\mathrm{D}$ \\
\hline $\mathbf{6 3}$ & $\mathrm{D}$ & $\mathrm{N}$ & $\mathrm{D}$ & $\mathrm{D}$ & $\mathrm{D}$ \\
\hline $\mathbf{6 4}$ & $\mathrm{A}$ & $\mathrm{D}$ & $\mathrm{A}$ & $\mathrm{D}$ & $\mathrm{D}$ \\
\hline $\mathbf{7 8}$ & $\mathrm{A}$ & $\mathrm{D}$ & $\mathrm{D}$ & $\mathrm{D}$ & $\mathrm{D}$ \\
\hline $\mathbf{8 0}$ & $\mathrm{A}$ & $\mathrm{A}$ & $\mathrm{D}$ & $\mathrm{D}$ & $\mathrm{D}$ \\
\hline $\mathbf{8 3}$ & $\mathrm{A}$ & $\mathrm{D}$ & $\mathrm{A}$ & $\mathrm{D}$ & $\mathrm{D}$ \\
\hline $\mathbf{8 4}$ & $\mathrm{A}$ & $\mathrm{D}$ & $\mathrm{A}$ & $\mathrm{N}$ & $\mathrm{N}$ \\
\hline $\mathbf{8 5}$ & $\mathrm{D}$ & $\mathrm{D}$ & $\mathrm{D}$ & $\mathrm{D}$ & $\mathrm{D}$ \\
\hline $\mathbf{9 6}$ & $\mathrm{A}$ & $\mathrm{A}$ & $\mathrm{A}$ & $\mathrm{A}$ & $\mathrm{D}$ \\
\hline $\mathbf{9 8}$ & $\mathrm{A}$ & $\mathrm{A}$ & $\mathrm{A}$ & $\mathrm{D}$ & $\mathrm{D}$ \\
\hline $\mathbf{9 9}$ & $\mathrm{A}$ & $\mathrm{D}$ & $\mathrm{A}$ & $\mathrm{D}$ & $\mathrm{A}$ \\
\hline $\mathbf{1 0 2}$ & $\mathrm{A}$ & $\mathrm{D}$ & $\mathrm{A}$ & $\mathrm{N}$ & $\mathrm{D}$ \\
\hline $\mathbf{1 0 5}$ & $\mathrm{D}$ & $\mathrm{A}$ & $\mathrm{D}$ & $\mathrm{D}$ & $\mathrm{D}$ \\
\hline $\mathbf{1 0 6}$ & $\mathrm{A}$ & $\mathrm{D}$ & $\mathrm{A}$ & $\mathrm{D}$ & $\mathrm{A}$ \\
\hline $\mathbf{1 0 8}$ & $\mathrm{A}$ & $\mathrm{D}$ & $\mathrm{D}$ & $\mathrm{D}$ & $\mathrm{D}$ \\
\hline
\end{tabular}

Note. $\mathrm{A}=$ Agree, $\mathrm{D}=$ Disagree, $\mathrm{N}=$ No Comment.

a Tabulations are done based on comments made that agree with any of the dissenting views presented for each category. ${ }^{b}$ These views are related to the profit-loss statement, other comprehensive income, and recycling (Chapter 7 - Questions 12, 13 \& 14 of Exposure Draft). ${ }^{c}$ These views are related to the definitions of liabilities and equity (Chapter 4 - Questions $3 \mathrm{~b}$ $\& 3 \mathrm{c}$ of Exposure Draft). ${ }^{\mathrm{d}}$ This view is related to the reintroduction of prudence (Chapter 2 Question 1b of Exposure Draft). ${ }^{\mathrm{e}}$ These views are related to the definitions and descriptions of the measurement bases (Chapter 6 - Questions $8 \mathrm{a} \& 8 \mathrm{~b}$ of Exposure Draft). ${ }^{\mathrm{f}}$ These views are related to the selection of a measurement basis (Chapter 6 - Question 9 of Exposure Draft).

Table 5. Continued

\begin{tabular}{|c|c|c|c|c|c|}
\hline \multirow[b]{2}{*}{ C.L. \# } & \multicolumn{5}{|c|}{ Question Number } \\
\hline & $\begin{array}{l}\text { AV2-AV7 \& } \\
\text { AV29-AV33 }^{\text {b }}\end{array}$ & AV8-AV14 ${ }^{c}$ & $\operatorname{AV} 16^{d}$ & $\begin{array}{l}\text { AV17-AV22 \& } \\
\text { AV27-AV28 }\end{array}$ & AV 23-AV26 ${ }^{\mathrm{f}}$ \\
\hline 114 & $\mathrm{~A}$ & $\mathrm{D}$ & $\mathrm{D}$ & $\mathrm{D}$ & $\mathrm{D}$ \\
\hline 118 & A & A & A & A & $\mathrm{D}$ \\
\hline 126 & A & $\mathrm{D}$ & A & $\mathrm{D}$ & $\mathrm{D}$ \\
\hline
\end{tabular}




\begin{tabular}{|c|c|c|c|c|c|}
\hline 130 & A & D & D & $\mathrm{D}$ & D \\
\hline 132 & A & A & A & $\mathrm{D}$ & $\mathrm{D}$ \\
\hline 148 & $\mathrm{D}$ & $\mathrm{D}$ & A & $\mathrm{D}$ & $\mathrm{D}$ \\
\hline 149 & A & $\mathrm{D}$ & D & $\mathrm{D}$ & D \\
\hline 157 & A & $\mathrm{D}$ & A & A & $\mathrm{D}$ \\
\hline 165 & A & $\mathrm{D}$ & D & A & A \\
\hline 167 & A & $\mathrm{D}$ & D & $\mathrm{D}$ & D \\
\hline 172 & A & $\mathrm{D}$ & D & $\mathrm{D}$ & D \\
\hline 174 & $\mathrm{D}$ & $\mathrm{D}$ & A & $\mathrm{D}$ & $\mathrm{D}$ \\
\hline 177 & A & $\mathrm{D}$ & D & $\mathrm{D}$ & $\mathrm{D}$ \\
\hline 178 & A & A & D & A & $\mathrm{D}$ \\
\hline 179 & A & A & D & $\mathrm{D}$ & $\mathrm{D}$ \\
\hline 180 & A & A & A & A & D \\
\hline 182 & A & $\mathrm{D}$ & D & $\mathrm{D}$ & $\mathrm{D}$ \\
\hline 183 & A & $\mathrm{N}$ & A & A & $\mathrm{D}$ \\
\hline 188 & A & $\mathrm{D}$ & D & $\mathrm{D}$ & D \\
\hline 189 & A & A & D & $\mathrm{D}$ & D \\
\hline 192 & A & $\mathrm{D}$ & D & $\mathrm{D}$ & D \\
\hline 197 & A & $\mathrm{D}$ & A & $\mathrm{D}$ & D \\
\hline 199 & A & $\mathrm{D}$ & D & $\mathrm{D}$ & D \\
\hline 200 & A & A & D & A & A \\
\hline 201 & A & A & D & A & D \\
\hline 203 & A & D & A & A & A \\
\hline 204 & A & D & A & D & D \\
\hline 205 & A & $\mathrm{D}$ & A & $\mathrm{D}$ & A \\
\hline 207 & A & A & D & $\mathrm{D}$ & D \\
\hline 208 & A & A & D & A & A \\
\hline 209 & A & D & D & $\mathrm{D}$ & D \\
\hline 210 & A & A & A & D & D \\
\hline 211 & $\mathrm{D}$ & A & D & $\mathrm{D}$ & $\mathrm{D}$ \\
\hline
\end{tabular}

Note. $\mathrm{A}=$ Agree, $\mathrm{D}=$ Disagree, $\mathrm{N}=$ No Comment.

a Tabulations are done based on comments made that agree with any of the dissenting views presented for each category. ${ }^{b}$ These views are related to the profit-loss statement, other comprehensive income, and recycling (Chapter 7 - Questions 12, 13 \& 14 of Exposure Draft). ${ }^{c}$ These views are related to the definitions of liabilities and equity (Chapter 4 - Questions $3 \mathrm{~b}$ $\& 3 \mathrm{c}$ of Exposure Draft). ${ }^{\mathrm{d}}$ This view is related to the reintroduction of prudence (Chapter 2 Question 1b of Exposure Draft). ${ }^{\mathrm{e}}$ These views are related to the definitions and descriptions of the measurement bases (Chapter 6 - Questions 8a \& 8b of Exposure Draft). ${ }^{\mathrm{f}}$ These views are related to the selection of a measurement basis (Chapter 6 - Question 9 of Exposure Draft). 


\section{Macrothink}

Table 5. Continued

\begin{tabular}{|c|c|c|c|c|c|}
\hline \multirow[b]{2}{*}{ C.L. \# } & \multicolumn{5}{|c|}{ Question Number } \\
\hline & $\begin{array}{l}\text { AV2-AV7 \& } \\
\text { AV29-AV33 }^{\text {b }}\end{array}$ & AV8-AV14 & $\operatorname{AV}^{\mathrm{d}}{ }^{\mathrm{d}}$ & $\begin{array}{c}\text { AV17-AV22 \& } \\
\text { AV27-AV28 }\end{array}$ & $\operatorname{AV} 23-A V 26^{f}$ \\
\hline 212 & $\mathrm{~A}$ & $\mathrm{D}$ & $\mathrm{D}$ & $\mathrm{D}$ & $\mathrm{A}$ \\
\hline 213 & $\mathrm{~A}$ & $\mathrm{~A}$ & $\mathrm{D}$ & $\mathrm{D}$ & $\mathrm{D}$ \\
\hline 214 & $\mathrm{~A}$ & $\mathrm{D}$ & $\mathrm{A}$ & $\mathrm{D}$ & $\mathrm{D}$ \\
\hline 215 & $\mathrm{~A}$ & $\mathrm{D}$ & $\mathrm{A}$ & $\mathrm{D}$ & $\mathrm{A}$ \\
\hline 216 & $\mathrm{~A}$ & $\mathrm{D}$ & $\mathrm{D}$ & $\mathrm{D}$ & $\mathrm{D}$ \\
\hline 217 & $\mathrm{~A}$ & $\mathrm{~A}$ & $\mathrm{D}$ & A & $\mathrm{D}$ \\
\hline$\# \mathbf{A}$ & 65 & 22 & 34 & 15 & 10 \\
\hline \# D & 7 & 48 & 38 & 55 & 61 \\
\hline$\# \mathbf{N}$ & $\mathbf{0}$ & 2 & $\mathbf{0}$ & 2 & 1 \\
\hline$\% \mathrm{~A}$ & $90 \%$ & $30 \%$ & $47 \%$ & $21 \%$ & $14 \%$ \\
\hline$\% \mathrm{D}$ & $10 \%$ & $67 \%$ & $53 \%$ & $76 \%$ & $85 \%$ \\
\hline$\% \mathrm{~N}$ & $\mathbf{0 \%}$ & $3 \%$ & $0 \%$ & $3 \%$ & $1 \%$ \\
\hline
\end{tabular}

Note. $\mathrm{A}=$ Agree, $\mathrm{D}=$ Disagree, $\mathrm{N}=$ No Comment.

${ }^{a}$ Tabulations are done based on comments made that agree with any of the dissenting views presented for each category. ${ }^{b}$ These views are related to the profit-loss statement, other comprehensive income, and recycling (Chapter 7 - Questions 12, 13 \& 14 of Exposure Draft). ${ }^{c}$ These views are related to the definitions of liabilities and equity (Chapter 4 - Questions $3 \mathrm{~b}$ $\& 3 \mathrm{c}$ of Exposure Draft). ${ }^{\mathrm{d}}$ This view is related to the reintroduction of prudence (Chapter 2 Question 1b of Exposure Draft). ${ }^{\mathrm{e}}$ These views are related to the definitions and descriptions of the measurement bases (Chapter 6 - Questions $8 \mathrm{a} \& 8 \mathrm{~b}$ of Exposure Draft). ${ }^{\mathrm{f}}$ These views are related to the selection of a measurement basis (Chapter 6 - Question 9 of Exposure Draft).

\section{Appendix A}

Exposure Draft Questions

\begin{tabular}{|c|l|}
\hline $\begin{array}{c}\text { Question } \\
\text { Number }\end{array}$ & \multicolumn{1}{c|}{ Question } \\
\hline $1 \mathrm{a}$ & $\begin{array}{l}\text { Do you support the proposals to give more prominence, within the objective of } \\
\text { financial reporting, to the importance of providing information needed to assess } \\
\text { management's stewardship of the entity's resources? }\end{array}$ \\
\hline $1 \mathrm{~b}$ & $\begin{array}{l}\text { Do you support the proposals to reintroduce an explicit reference to the notion } \\
\text { of prudence (described as caution when making judgements under conditions of } \\
\text { uncertainty) and to state that prudence is important in achieving neutrality? }\end{array}$ \\
\hline $1 \mathrm{c}$ & $\begin{array}{l}\text { Do you support the proposals to state explicitly that a faithful representation } \\
\text { represents the substance of an economic phenomenon instead of merely } \\
\text { representing its legal form? }\end{array}$ \\
\hline
\end{tabular}




\begin{tabular}{|c|c|}
\hline $1 d$ & $\begin{array}{l}\text { Do you support the proposals to clarify that measurement uncertainty is one } \\
\text { factor that can make financial information less relevant, and that there is a } \\
\text { trade-off between the level of measurement uncertainty and other factors that } \\
\text { make information relevant? }\end{array}$ \\
\hline $1 \mathrm{e}$ & $\begin{array}{l}\text { Do you support the proposals to continue to identify relevance and faithful } \\
\text { representation as the two fundamental qualitative characteristics of useful } \\
\text { financial information? }\end{array}$ \\
\hline $2 \mathrm{a}$ & $\begin{array}{l}\text { Do you agree with the proposed description of a reporting entity in paragraphs } \\
3.11-3.12 \text { ? }\end{array}$ \\
\hline $2 b$ & $\begin{array}{l}\text { Do you agree with the discussion of the boundary of a reporting entity in } \\
\text { paragraphs } 3.13-3.25 \text { ? }\end{array}$ \\
\hline $3 \mathrm{a}$ & $\begin{array}{l}\text { Do you agree with the proposed definitions of an asset, and the related } \\
\text { definition of an economic resource? }\end{array}$ \\
\hline $3 b$ & Do you agree with the proposed definitions of a liability? \\
\hline $3 \mathrm{c}$ & Do you agree with the proposed definitions of equity? \\
\hline $3 d$ & Do you agree with the proposed definitions of income? \\
\hline $3 e$ & Do you agree with the proposed definitions of expenses? \\
\hline 4 & $\begin{array}{l}\text { Do you agree with the proposed description of a present obligation and the } \\
\text { proposed guidance to support the description? }\end{array}$ \\
\hline $\begin{array}{c}5 \\
\text { (Not Used) } \\
\end{array}$ & $\begin{array}{l}\text { Do you have any comments on the proposed guidance? Do you believe that } \\
\text { additional guidance is needed? }\end{array}$ \\
\hline 6 & Do you agree with the proposed approach to recognition? \\
\hline 7 & Do you agree with the proposed discussion of derecognition? \\
\hline $8 \mathrm{a}$ & $\begin{array}{l}\text { Has the IASB correctly identified the measurement bases that should be } \\
\text { described in the Conceptual Framework? }\end{array}$ \\
\hline $8 \mathrm{~b}$ & $\begin{array}{l}\text { Has the IASB properly described the information provided by each of the } \\
\text { measurement bases, and their advantages and disadvantages? }\end{array}$ \\
\hline 9 & $\begin{array}{l}\text { Has the IASB correctly identified the factors to consider when selecting a } \\
\text { measurement basis? }\end{array}$ \\
\hline 10 & $\begin{array}{l}\text { Do you agree with the approach discussed in paragraphs 6.74-6.77 and } \\
\text { BC6.68? }\end{array}$ \\
\hline $\begin{array}{c}11 \\
\text { (Not Used) }\end{array}$ & $\begin{array}{l}\text { Do you have any comments on the discussion of the objective and scope of } \\
\text { financial statements, and on the use of presentation and disclosure as } \\
\text { communication tools? }\end{array}$ \\
\hline 12 & Do you support the proposed description of the statement of profit or loss? \\
\hline 13 & $\begin{array}{l}\text { Do you agree with the proposals on the use of other comprehensive income? } \\
\text { Do you think that they provide useful guidance to the IASB for future decisions } \\
\text { about the use of other comprehensive income? }\end{array}$ \\
\hline 14 & $\begin{array}{l}\text { Do you agree that the Conceptual Framework should include the rebuttable } \\
\text { presumption described above (recycling)? }\end{array}$ \\
\hline 15 & Do you agree with the analysis in paragraphs BCE.1 - BCE.31? \\
\hline 16 & Do you agree with the proposed approach to business activities? \\
\hline
\end{tabular}




\begin{tabular}{|c|l|}
\hline 17 & Do you agree with the IASB's conclusions on long-term investment? \\
\hline $\begin{array}{c}18 \\
(\text { Not Used) }\end{array}$ & Do you have comments on any other aspect of the Exposure Draft? \\
\hline
\end{tabular}

\section{Appendix B}

Comment Letter Information List

\begin{tabular}{|c|c|c|c|}
\hline C.L.\# & Date & Respondent & Organization \\
\hline 4 & $11 / 2 / 2015$ & Denise Laufer & SwissHoldings \\
\hline 8 & $11 / 13 / 2015$ & Lyn Grigg & HoTARAC \\
\hline 13 & $11 / 17 / 2015$ & Henry Chan & The Hong Kong Association of Banks \\
\hline 14 & $11 / 18 / 2015$ & \begin{tabular}{ll|} 
Brian & Singleton \\
Green & \\
\end{tabular} & $\begin{array}{l}\text { The Institute of Chartered Accountants in England } \\
\text { and Wales }\end{array}$ \\
\hline 15 & $11 / 18 / 2015$ & Petr Krtz & The Federation of European Accountants \\
\hline 16 & $11 / 19 / 2015$ & Kenneth C. Sharp & Grant Thornton International Ltd \\
\hline 18 & $11 / 19 / 2015$ & David Ogloza & Insurance Europe \\
\hline 20 & $11 / 19 / 2015$ & Kimberley Crook & New Zealand Accounting Standards Board \\
\hline 24 & $11 / 24 / 2015$ & Liz Murrall & The Investment Association \\
\hline 29 & $11 / 25 / 2015$ & Omindi Nixon & Institute of Certified Public Accountants of Kenya \\
\hline 33 & $11 / 25 / 2015$ & Amy Hutchinson & The Institute of Chartered Accountants of Scotland \\
\hline 35 & $11 / 26 / 2015$ & Mark Causevic & International Association of Insurance Supervisors \\
\hline 36 & $11 / 26 / 2015$ & Roger Collinge & UK Shareholders' Association \\
\hline 38 & $11 / 27 / 2015$ & David Chitty & Crowe Horwath International \\
\hline 42 & $12 / 1 / 2015$ & Vicki Stylianou & The Institute of Public Accountants [Australia] \\
\hline 51 & $11 / 10 / 2015$ & Niclas Hellman & European Accounting Association \\
\hline 52 & $11 / 17 / 2015$ & Steven Maijoor & ESMA \\
\hline 56 & $11 / 20 / 2015$ & Romuald Bertl & AFRAC \\
\hline 61 & $11 / 23 / 2015$ & Bee Leng Tan & Malaysian Accounting Standards Board \\
\hline 63 & $11 / 23 / 2015$ & Upendra Wijesingha & The Institute of Chartered Accountants of Sri Lanka \\
\hline 64 & $11 / 23 / 2015$ & $\begin{array}{l}\text { Hans-Juergen } \\
\text { Saeglitz }\end{array}$ & German Insurance Association \\
\hline 78 & $11 / 24 / 2015$ & $\begin{array}{l}\text { SEUNG KYOUNG } \\
\text { YOO }\end{array}$ & The Korean Institute of Certified Public Accountants \\
\hline 80 & $11 / 24 / 2015$ & Andreas Barckow & ASCG \\
\hline 83 & $11 / 24 / 2015$ & Dorothee Bucquet & IIF \\
\hline 84 & $11 / 24 / 2015$ & Kuai Cheng & individual \\
\hline 85 & $11 / 24 / 2015$ & Dominic Mathon & Unilever PLC \\
\hline 96 & $11 / 25 / 2015$ & Asher Curtis & FRPC/FARS/AAA \\
\hline 98 & $11 / 25 / 2015$ & Shane Buggle & Australia and New Zealand Banking Group Limited \\
\hline 99 & $11 / 25 / 2015$ & $\begin{array}{l}\text { MULALA } \\
\text { RATSHITANGA }\end{array}$ & SAICA \\
\hline
\end{tabular}




\begin{tabular}{|l|c|l|l|}
\hline 102 & $11 / 25 / 2015$ & Keiko KISHIGAMI & JICPA \\
\hline 105 & $11 / 25 / 2015$ & Antonio Corbi & ISDA \\
\hline 106 & $11 / 25 / 2015$ & Muhammad Owais & Institute of Chartered Accountants of Pakistan \\
\hline 108 & $11 / 25 / 2015$ & Gregory Hodgkiss & ACTEO - AFEP - MEDEF \\
\hline 114 & $11 / 25 / 2015$ & Silvio Takahashi & CPC Brazil \\
\hline 118 & $11 / 25 / 2015$ & Kevin Williams & The 100 Group \\
\hline 126 & $11 / 25 / 2015$ & David Chopping & Moore Stephens LLP \\
\hline 130 & $11 / 25 / 2015$ & Tomasz Wesolowski & Private \\
\hline 132 & $11 / 25 / 2015$ & Richard Martin & ACCA \\
\hline 148 & $10 / 6 / 2015$ & Bjoern Schneider & The Linde Group \\
\hline 149 & $10 / 5 / 2015$ & A T Whitfield & Australasian Council of Auditors-General \\
\hline 157 & $10 / 20 / 2015$ & Neville Mitchell & Group of 100 Inc. [Australia] \\
\hline 165 & $11 / 2 / 2015$ & Suat Cheng Goh & Singapore Accounting Standards Council \\
\hline & $10 / 22 / 2015$ & Sofia & \\
Bildstein-Hagberg & Confederation of Swedish Enterprise \\
\hline 167 & & & \\
\hline
\end{tabular}

Appendix B Continued

\begin{tabular}{|c|c|l|l|}
\hline C.L. \# & Date & Respondent & Organization \\
\hline 172 & $11 / 25 / 2015$ & Carlos Montalvo & $\begin{array}{l}\text { European Insurance and Occupational Pensions } \\
\text { Authority }\end{array}$ \\
\hline 174 & $11 / 26 / 2015$ & Erlend Kval & Norwegian Accounting Standards Board \\
\hline 177 & $11 / 25 / 2015$ & Richard Middleton & Association for Financial Markets in Europe \\
\hline 178 & $11 / 25 / 2015$ & Tony Debell & PwC \\
\hline 179 & $11 / 25 / 2015$ & Paulo José Alves & PETROBRAS \\
\hline 180 & $11 / 25 / 2015$ & Michele Gomes & Bradesco \\
\hline 182 & $11 / 25 / 2015$ & Felipe Perez Cervantes & CINIF \\
\hline 183 & $11 / 25 / 2015$ & Felipe Pérez Cervantes & GLASS \\
\hline 188 & $11 / 26 / 2015$ & Emilio Linares-Rivas & REPSOL \\
\hline 189 & $11 / 26 / 2015$ & Agnieszka Stachniak & Polish Accounting Standards Committee \\
\hline & & & European Federation of Accountants and Auditors \\
for SMEs
\end{tabular}




\begin{tabular}{|l|l|l|l|}
\hline 210 & $11 / 30 / 2015$ & Barbet Massin Michel & MAZARS \\
\hline 211 & $12 / 1 / 2015$ & Mark Omona & $\begin{array}{l}\text { Institute of Certified Public Accountants of } \\
\text { Uganda }\end{array}$ \\
\hline 212 & $12 / 1 / 2015$ & Djohan Pinnarwan & $\begin{array}{l}\text { The Indonesian Financial Accounting Standards } \\
\text { Board }\end{array}$ \\
\hline 213 & $12 / 1 / 2015$ & Ana M Martinez-Fina & Accounting and Auditing Institute of Spain \\
\hline 214 & $12 / 1 / 2015$ & Marta Soto Bodí & Telefónica, S.A. \\
\hline 215 & $12 / 2 / 2015$ & Yu Chen & China Accounting Standards Committee \\
\hline 216 & $12 / 2 / 2015$ & Christina Ng & HKICPA \\
\hline 217 & $12 / 2 / 2015$ & Victoria O'Leary & Ernst \& Young \\
\hline
\end{tabular}

\section{Copyright Disclaimer}

Copyright for this article is retained by the author(s), with first publication rights granted to the journal.

This is an open-access article distributed under the terms and conditions of the Creative Commons Attribution license (http://creativecommons.org/licenses/by/3.0/). 